\title{
KEDUDUKAN BADAN USAHA MILIK DESA (BUMDES) BERDASARKAN UNDANG-UNDANG NOMOR 11 TAHUN 2020 TENTANG CIPTA KERJA
}

\author{
THE POSITION OF VILLAGE OWNED BUSINESS ENTITIES (BUMDES) BASED ON LAW NO. 11 \\ OF 2020 CONCERNING JOB CREATION
}

Jusman Khairul Hadi

Fakultas Hukum Universitas Gunung Rinjani

jusmankhairulhadi@gmail.com

\section{Info Artikel}

Sejarah Artikel :

Diterima 27 Okt 2021

Disetujui 18 Nov 2021

Publikasi November 2021

\section{Keyword:}

BUMDes,

Business Entities,

Legal Entities.

\section{Albstract}

The purpose of this research is what are the changes in the regulation of the position of BUMDes and the strengthening of BUMDes based on Law Number 11 of 2020 concerning Job Creation. The methodof this research used was normative juridical with a statutory approach whose data sources are secondary data consisting of primary, secondary and tertiary legal materials with data collection methods by means of library research. Data analysis was carried out starting from the hierarchy of laws and regulations and expert opinions. With the enactment of the Job Creation Act, it confirms the status of BUMDes as a legal entity, and BUMDes fulfils it as a Public Legal entity, thus, BUMDes has legal personality and legal capacity, especially in the field of civil law, and the debate about the status of BUMDes after the Job Creation Law is considered completed.

\section{Ahstrak}

Tujuan dari penelitian ini adalah apa saja perubahan pengaturan kedudukan BUMDes dan penguatan BUMDes berdasarkan UndangUndang Nomor 11 Tahun 2020 Tentang Cipta Kerja. Metode penelitian yang digunakan adalah yuridis normative dengan pendekatan perundang-undangan yang sumber datanya dari data sekunder terdiri dari bahan hukum primer, sekunder dan tersier dengan metode pengumpulan data dengan cara studi kepustakaan. Analisis data dilakukan mulai dari hirarkhi peraturan perundanganundangan dan pendapat para ahli. Dengan lahirnya UU Cipta Kerja ini menegaskan setatus BUMDes sebagai badan Hukum, dan BUMDes memenuhi sebagai badan Hukum Publik, dengan demikian, BUMDes memiliki keperibadian hukum dan kapasitas hukum, khususnya dalam lapangan hukum keperdataan, dan perdebatan mengenai status BUMDes paska UU Cipta Kerja ini dianggap selesai. 


\section{A. PENDAhUlUan}

Badan Usaha Milik Desa yang selanjutnya di sebut BUMDes merupakan badan hukum sekaligus badan usaha yang di dirikan oleh desa dan/atau bersama desa-desa guna mengelola usaha, mengembangkan produktivitas dan investasi, memanfaatkan asset, menyediakan pelayanan dan/atau jenis usaha lainnya untuk tujuan sebesar-besarnya kesejahteraan masyarakat desa. Terkait dengan pendiriannya BUMDes dibangun atas inisiasi masyarakat dan pemerintah desa berdasarkan pada prinsip-prinsip kooperatif, partisipatif, transparansi, emansipatif, akuntabel dan sustainebel. Yang terpenting adalah BUMdes didalam pengolaannya harus dilakukan secara profesinal dan mandiri. BUMDes dalam hal ini merupakan pilar kegiatan ekonomi yang ada di desa dengan fungsi sebagai lembaga sosial yang berpihak kepada kepentingan masyarakat melalui kontribusinya dalam penyediaan pelayanan sosial, dan sebagai lembaga komersial bertujuan mencari keuntungan melalui sumber daya local atau barang dan jasa kepasar, untuk itu dalam menjalankan usahanya prinsip efektifitas dan efisiensi betul-betul ditekankan.

Dalam rangka penguatan ekonomi pedesaan dalam hal ini adalah BUMDes menjadi bagian penting dan juga bisa menjadi titik lemah dalam rangka mendukung penguatan ekonomi pedesaan. Oleh sebab itu dibutuhkan upaya-upaya strategi dan sistematis dalam rangka mendorong BUMDes agar mampu mengelola aset ekonomi desa sekaligus mengembangkan jaringan ekonomi demi meningkatkan daya saing ekonomi perdesaan. Dalam hal ini, BUMDes merupakan bentuk konsolidasi atau penguatan terhadap lembaga-lembaga ekonomi desa. Beberapa agenda yang bisa dilakukan dalam pengembangan kemampuan Sumber Daya Manusia sehingga mampu memberikan nilai tambah dalam pengelolaan aset ekoomi desa yang terdiri dari:
(1) Mengintekgrasikan
produk-produk ekonomi desa sehingga memiliki posisi nilai tawar yang baik dalam jaringan pasar.
(2) Merealisasikan ekonomi yang kompetitif terhadap usaha yang di kembangkan

(3) Memperkuat kelembagaan ekonomi desa; dan

(4) Mengembangkan unsur pendukung lainya seperti informasi pasar, dukungan teknologi dan menajemen prasarana ekonomi, jaringan komunikasi maupun dukungan regulasi dan pembinaan.

Pengembangan basis ekonomi di pedesaan sebenarnya sudah sejak lama yang di jalankan oleh pemerintahan melalui berbagai progam. Namun lebih kepada program yang bersifat top down- inisiasi dari pusat, desa hanya pelaksana. Bentuk pengembangannyapun lebih condong seragam, tidak didasarkan pada kondisi, kultur dan potensi di daerah yang cenderung berbeda-beda. Disamping tidak adanya regulasi yang mendorong kreatifitas muncul, ada pula rasa takut melangkah, menghindari kesalahan dan mencari rasa aman.

Pada tahun 1992, pemerintah telah mengalakkan bentuk usaha berupa koperasi yang dinamakan Koperasi Unit Desa, yang di tandai dengan terbitnya Undang-Undang Nomor 25 Tahun 1992 Tentang Perkoperasian. Namun badan usaha koperasi tersebut gagal mengangkat ekonomi di pedesaan. Koperasi cenderung di gunakan sebagai alat ekonomi bagi juragan-juragan yang ada di pedesaan. Akibatnya koperasi hanya untuk mensejahterakan pemilik modalnya, jauh dari tujuan badan hukum koperasi itu sendiri yaitu ekonomi kerakyataan yang berusaha mensejahterakan anggotanya.

Dengan munculnya semangat otonomi daerah, muncul gagasan untuk memperkuat badan usaha di daerah. Untuk itu pemerintah mengeluarkan kebijakan baru untuk menubuh kembangkan perekonomian daerah dengan mengeluarkan Undang-Undang Nomor 32 Tahun 2004 Tentang Pemerintah Daerah. Pasal 213 ayat (1) Undang-Undang tersebut menyebutkan, bahwa desa dapat mendirikan BUMDes sesuai dengan kebutuhan dan potensi desa.

BUMDes yang merupakan lembaga usaha desa yang bergerak khusus dibidang ekonomi dengan tujuan meningkatkan prekonomian desa, meningkatkan pendapatan asli desa, meningkatkan pengelolaan potensi desa yang sesuai dengan kebutuhan masyarakat dan menjadi tulang punggung pertumbuhan 
pemerataan ekonomi desa dalam upaya meningkatkan kesejahteraan masyarakat. ${ }^{1}$

Otonomi daerah adalah kewenangan untuk mengatur urusan dan kepentingan masyarakat di daerahnya sendiri. Setelah reformasi, lahir perundang-undangan dalam penyelenggaraan pemerintah daerah yaitu UU 22/1999 yang diganti dengan UU 32/2004, sampai akhirnya terjadi perubahan melalui UU 23/2014 Tentang Pemerintahan Daerah, membawa pengaruh besar terhadap penyelenggaran pemerintahan desa, yaitu dengan lahirrnya UU 6/2014 tentang Desa selanjutnya disingkat dengan UU Desa. ${ }^{2}$

Disamping menempatkan provinsi dan kabupaten/kota sebagai sarana pelaksanaan otonomi daerah, pemerintah memandang bahwa desa sudah saatnya melaksanakan otonominya. Otonomi yang dimaksud adalah Implementasi otonomi desa dengan disahkannya UU Desa, yang memberikan peluang pada desa untuk membangun desa dengan mendirikan BUMDes yang dan dikukung dengan PP 43/2014 dan PP 47/2015 tentang Perubahan PP 43/2014 Tentang Peraturan Pelaksanaan UU 6/2014 Tentang Desa, khususnya BAB VIII Tentang BUM Desa, Permendes 4/2015 tentang Pendirian, Pengurusan dan Pengelolan, dan Pembubaran Badan Usaha Milik Desa, dan PP 60/2014 Tentang Dana Desa yang bersumber dari Anggaran Pendapatan Belanja Negara (APBN), telah memberikan pondasi dasar yang berkaitan penyelengaraan pemerintah desa dan pemberdayaan masyarakat desa sebagai bentuk daerah otonom. Dengan demikian untuk membangun dan memajukan suatu desa, pemerintah desa dianjurkan untuk memiliki BUMDes yang berguna untuk membangun, kemajuan dan potensi desa. Ketentuan ini di buat oleh pemerintah pusat tidak lain agar desa turut serta atau berpartisipasi dan turun langsung untuk meningkatkan ekonomi desa demi tewujudnya masyarakat adil makmur sesuai dengan yang tercantum dalam UU Desa. ${ }^{3}$

Badan Usaha Milik Desa yang selanjutnya di sebut BUMDes adalah badan usaha yang di

${ }^{1}$ https://www.berdesa.com/4-tujuan-pendirianbumdesa/ (diakses tanggaL I7 Maret 2021 Jam 13:39).

2 Utang Rosidin, Pemberdayaan Desa Dalam Sistem Pemerintahan Daerah, (Bandung: CV Pustaka Setia,2019), hlm3.

3 Ibid. dirikan oleh pemerintah desa dan masyarakat yang disepakati melalui musyawarah desa dengan semangat gotong royong untuk membangun dan mengembangkan potensi desa di bidang ekonomi atau pelayanan umum dalam rangka meningkatkan kesejahteraan masyarakat desa sesuai dengan amanah UU Desa. Namun posisi dan keberadaan BUMDes menjadi suatu permasalahan yang berbelit-belit ketika UUDes, menyebutkan BUMDes sebagai badan usaha, namun belum tegas tertulis dari kedudukan BUMDes itu sendiri. Masalah lain yang muncul yaitu BUMDes sulit menjalin kerja sama bisnis dengan pihak lain, BUMDes juga sulit menjangkau modal perbankan, dan kesempatan perluasan usaha BUMDes pun menjadi terhambat dikarenakan tidak ada legal standing (kedudukan yang sah di hadapan hukum) sehingga BUMDes sulit bermitra secara setara dengan yang lain. Oleh karena itu BUMDes harus ada solusi dari pemangku yang berwewenang mengenai legal standing nya, sehingga dengan lahirlah Undang-Undang Nomor 11 Tahun 2020 tentang Cipta Kerja (disingkat UU Cipta Kerja), dalam ketentuan Pasal 117 menegaskan, "bahwa Badan Usaha Milik Desa yang selanjutnya disebut BUM Desa adalah Badan hukum yang didirikan oleh desa dan atau bersama desa-desa guna mengelola usaha, memanfaatkan aset, mengembangkan investasi dan produktivitas, menyediakan jasa pelayanan, dan atau jenis usaha lainnya untuk sebesar-besarnya kesejahteraan masyarakat desa ${ }^{4} . "$

Pada bagian lain dari UU Cipta Kerja, yaitu di bagian ke-10 pasal 117 tentang Badan Usaha Milik Desa, yang dimana pasal 117 mengubah ketentuan pasal 1 angka 6 UU Desa yang berbunyi, "Badan Usaha Milik Desa, yang selanjutnya disebut BUMDes, adalah badan usaha yang seluruh atau sebagian besar modalnya dimiliki oleh desa melalui penyertaan secara langsung yang berasal dari kekayaan desa yang di pisahkan guna mengelola aset, jasa pelayanan, dan usaha lainnya untuk sebesar-besarnya kesejahteraan masyarakat Desa". 5 Hal ini

4 Republik Indoneia, Undang-Undang Nomor 11 Tahun 2020 Tentang Cipta Kerja, hlm. 681.

5 Republik Indonesia, Undang-Undang Nomor 6 Tahun 2014 Tentang Desa, hlm. 3, pasal 1, angka 6. 
menandakan bahwa sebelumnya tertuliskan bahwa modal BUMDes dimiliki oleh desa. Sebab, merupakan kekayaan desa yang diberikan melalui penyertaan langsung. Dan ketentuan ini kini di ubah yang selanjutnya berbunyi, "Badan Usaha Milik Desa, yang selanjutnya di sebut BUMDes, adalah badan hukum yang didirikan oleh desa dan/atau bersama desa-desa guna mengelola usaha, memanfaatkan aset, mengembangkan investasi dan produktivitas, menyediakan jasa pelayanan, dan/atau jenis usaha lainnya untuk sebesar-besarnya kesejahteraan masyarakat desa". Artinya bahwa desa hanya berperan untuk mengelola usaha aset yang sudah ada di BUMDes. Hanya saja, pemerintah desa bisa mendorong perkembangan BUMDes dengan memberikan hibah atau akses permodalan jika merujuk pada bunyi pasal 117 UU Cipta Kerja. Selanjutnya UU Cipta Kerja mengubah pasal 87 UU Desa. Pada perubahannya, ditambahkan ayat (4) dan ayat (5) yang menyatakan bahwa BUMDes dapat membentuk unit usaha berbadan hukum sesuai dengan kebutuhan dan tujuan. Kemudian pasal 5 menyatakan, bahwa seluruh ketentuan di ayat (1) sampai dengan ayat (4) pasal 87 di atur dengan Peraturan Pemerintah. Oleh karena itu lahirlah Peraturan Pemerintah Republik Indonesia Nomor 11 Tahun 2021 Tentang Badan Usaha Milik Desa selanjutnya disingkat PP BUMDes. Itu menandakan bahwa BUMDes mempunyai aturan yang dikhususkan (lex specialis) berbicara tentang BUMDes yang di anggap menjadi solusi dan penyempurnaan terkait kekurangan BUMDes sebelumnya, sehingga peneliti tertarik melakukan penelitian secara normatif karena aturan yang berlaku saat telah banyak perubahan terkait dengan BUMDes dengan fokus penelitian tentang "Bagaimana kedudukan BUMDes dan Bentuk Penguatan BUMDes berdasarkan UndangUndang Nomor 11 Tahun 2020 Tentang Cipta Kerja". Dari uraian latar belakang di atas, maka dapat dirumuskan masalah sebagai berikut apa saja perubahan pengaturan kedudukan BUMDes dan penguatan BUMDes berdasarkan Undang-Undang Nomor 11 Tahun 2020 Tentang Cipta Kerja.

\section{B. METODE PENELITIAN}

Penelitian merupakan suatu sarana (ilmiah) dalam pengembangan ilmu pengetahuan maupun teknologi. Hal ini disebabkan oleh karena penelitian bertujuan untuk mengungkapkan kebenaran secara sistematis, metodologis, dan konsisten. Melalui proses penelitian tersebut dilakukan analisa dan konstruksi terhadap data yang dikumpulkan dan diolah. ${ }^{6}$ Penelitian yang khusus dilakukan dalam konteks ilmu hukum adalah untuk mengetahui mengenai proses hukum, peristiwa hukum dan ketentuan peraturan hukum itu sendiri. Selain itu, juga untuk mengetahui subtansi maupun prosedur hukumnya. $^{7}$

Penelitian hukum dilakukan untuk mencari pemecahan atas isu hukum yang timbul, sehingga dapat dilakukan bahwa penelitian hukum merupakan suatu penelitian di dalam kerangka hukum, untuk mendapatkan preskripsi (petunjuk peraturan) terhadap apa yang seharusnya dilakukan terhadap isu yang dimunculkan. ${ }^{8}$ Melakukan suatu penelitian hukum pada dasarnya tidak dapat terlepas dari penggunaan metode penelitian. Sebab, setiap penelitian pasti menggunakan metode untuk menganalisa permasalahan yang diangkat. Metodologi pada hakekatnya memberikan pedoman, tentang cara-cara mempelajari, menganalisa dan memahami obyek yang ditelitinya. Metodologi merupakan unsur yang mutlak ada di dalam suatu penelitian. ${ }^{9}$

Kerena penelitian merupakan sarana ilmiah, maka metode penelitian merupakan prosedur dan teknik untuk menjawab permasalahan penelitian, karena itu penggunaan metode penelitian senantiasa disesuaikan dengan permasalahan apa yang akan diteliti dan bagaimana cara untuk menemukan pemecahan masalah tersebut, berikut metodelogi penelitian yang peneliti gunakan dalam penelitian ini, sebagai berikut:

\footnotetext{
${ }^{6}$ Soejono Soekanto, Sri Mamudji, Penelitian Hukum Normatif Suatu Tinjauan Singkat, (Jakarta: PT RajaGrafindo Persada, 2014), hlm. 1.

7 Sabian Utsman, Metodologi Penelitian Hukum Progresif, (Yogyakarta: Pustaka Pelajar ,2014), hlm. 1.

8 Peter Mahmud Marzuki, Penelitian Hukum, (Jakarta: Kencana, 2005), hlm. 41

9 Soerjono Soekanto, Pengantar Penelitian Hukum, (Jakarta: UI Press, 2014), hlm. 6-7
} 
pertama, jenis penelitian yang penulis pergunakan dalam penyusunan penulisan hukum ini adalah penelitian hukum normatif disebut juga penelitian hukum doktrinal. Pada penelitian hukum jenis ini, acapkali hukum dikonsepkan sebagai kaidah atau norma yang merupakan patokan berperilaku manusia yang dianggap pantas. ${ }^{10}$ Penelitian hukum normatif dibagi menjadi 7 (tujuh) jenis, yaitu: ${ }^{11}$ penelitian inventarisasi hukum postif, penelitian asas-asas hukum, penelitian hukum klinis, penelitian hukum yang mengkaji sistematika peraturan perundangundangan, penelitian hukum yang ingin menelaah sinkronisasi suatu peraturan perudang-undangan, penelitian perbandingan hukum dan penelitian sejarah hukum.

Kedua, metode pendekatan dalam penelitian hukum terdapat beberapa pendekatan, dengan pendekatan tersebut peneliti akan mendapatkan informasi dari berbagai aspek mengenai isu yang sedang dicari jawabnya. Pendekatan yang digunakan dalam peneltian hukum ini adalah pendekatan undang-undang (statute approach), dilakukan dengan menelaah semua Undang-Undang dan regulasi yang terkait dengan BUMDes, bagi peneliti untuk mempelajari adakah konsistensi dan kesesuaian antara suatu undang-undang dengan undang-undang lainnya atau antara regulasi dengan undang-undang. ${ }^{12}$ Selain pendekatan perundangan-undangan penelitian ini juga menggunakan pendekatan konseptual yang beranjak dari peraturanperaturan perudang-undangan dan doktrindoktrin yang berkembang di dalam ilmu hukum. Peneliti akan menemukan ide tentang pengertian hukum, asas-asas hukum dan konsep-konsep hukum yang sesuai dengan isu hukum yang diteliti yakni kedudukan BUMDes. ${ }^{13}$

Ketiga, jenis dan sumber data Hukum. Karena penelitian hukum ini adalah penelitian normatif atau doktrinal, maka jenis dan sumber data yang akan digunakan sebagai dasar untuk menunjang penelitian ini adalah data yang dikumpulkan berasal dari data

10 Amiruddin, Zainal Asikin, Pengantar Metode Penelitian Hukum, Edisi Revisi, (Jakarta: Raja Grafindo Persada, 2004), hlm. 118.

11 Ibid, hlm.120-132.

12 Peter Mahmud Marzuki, Op. Cit, hlm. 93

13 Ibid, hlm. 95 sekunder. Data sekunder dimaksud antara lain meliputi bahan hukum primer, bahan hukum sekunder dan bahan hukum tertsier berupa Norma Dasar, perundang-undangan, hasil penelitian ilmiah, buku-buku dan lain sebagainya. ${ }^{14}$. Bahan hukum primer yaitu bahan hukum yang mempunyai kekuatan mengikat sebagai landasan utama yang dipakai dalam rangka penelitian ini adalah UU 23/2014 Tentang Pemerintahan Daerah, UU 6/2014 tentang Desa, UU 11/2020 Tentang Cipta Kerja dan PP 11/2021 tentang Badan Usaha Milik Desa.

Sedangkan bahan hukum sekunder yaitu bahan hukum yang memberikan penjelasan bahan hukum primer, seperti hasil-hasil penelitian, hasil seminar, hasil karya dari kalangan hukum, serta dokumen-dokumen lain yang berkaitan dengan Badan Usaha Milik Desa. Bahan hukum ini terdiri dari buku atau jurnal hukum yang berisi mengenai prinsip-prinsip dasar (asas hukum), pandangan para ahli hukum (doktrin), hasil penelitian hukum, kamus hukum, dan ensiklopedia hukum. Wawancara dengan narasumber seorang ahli hukum untuk memberikan pendapat hukum tentang suatu fenomena bisa diartikan sebagai bahan hukum sekunder. Namun demikian, perlu dilihat kapasitas keilmuan dan seyogyanya tidak terlibat dengan kejadian tersebut agar komentar yang diberikan menjadi objektif. ${ }^{15}$ Sedangkan bahan hukum tensier yaitu bahan non hukum adalah bahan penelitian yang terdiri atas buku teks bukan hukum yang terkait dengan penelitian seperti buku politik, buku ekonomi, data sensus, laporan tahunan perusahaan, kamus bahasa dan ensiklopedia umum. Bahan ini menjadi penting karena mendukung dalam proses analisis hukumnya. ${ }^{16}$

Keempat, tehnik pengumpulan data dalam penelitian hukum normatif atau kepustakaan dilakukan dengan studi pustaka terhadap bahan-bahan hukum, baik bahan hukum primer, bahan hukum sekunder, maupun bahan hukum tersier dan atau bahan

\footnotetext{
${ }^{14}$ Amiruddin, Zainal Asikin, Op. Cit, hlm. 118-119.

15 Peter Mahmud Marzuki, Op. Cit. hlm. 169

${ }^{16}$ Ibid
} 
non hukum. Penelusuran bahan hukum tersebut dengan melalui media internet. ${ }^{17}$

Kelima, analisis bahan hukum hasil penelitian merupakan kegiatan yang berupa telaah terhadap hasil pengolahan berupa bahan penelitian dengan kajian pustaka yang telah dilakukan sebelumnya. Analisis hasil penelitian ini dilakukan dengan cara mengkritisi, mendukung, atau memberi komentar, kemudian membuat suatu kesimpulan terhadap hasil penelitian dengan pikiran sendiri dan bantuan kajian pustaka. Metode analisis untuk jenis penelitian hukum normatif berupa metode preskriptif yaitu metode analisis yang memberikan penilaian (justifikasi) tentang obyek yang diteliti apakah benar atau salah, atau apa yang seyogyanya menurut hukum. ${ }^{18}$

\section{PEMBAHASAN}

\section{Sejarah Badan Usaha Milik Negara di Indonesia}

Pengaturan pengelolaan Badan Usaha Milik Negara yang selanjutanya di sebut BUMN yang diatur dalam UU 19/2003 tentang Badan Usaha Milik Negara diderivasi dari teori negara kesejahteraan (welfare state) yang secara eksplisit dianut dalam UUD 1945, sejak dari pembukaan hingga pasal-pasalnya. Pembentuk UUD 1945 yang diwarnai pemikiran negara kesejahteraan (welfare state) mencita-citakan pembentukan suatu pemerintah negara Indonesia yang melindungi segenap bangsa Indonesia dan mampu memajukan kesejahteraan umum. BUMN yang seluruh atau sebagian besar modalnya berasal dari kekayaan negara yang dipisahkan, merupakan salah satu pelaku ekonomi dalam sistem perekonomian nasional, di samping usaha swasta dan koperasi. Dalam menjalankan kegiatan usahanya, BUMN, swasta dan koperasi melaksanakan peran saling mendukung berdasarkan demokrasi ekonomi. ${ }^{19}$

17 Mukti Fajar dan Yulianto Achmad, Dualisme Penelitian Hukum Normatif dan Empiris, Cetakan IV, (Yogyakarta: Pustaka Pelajar, 2017), hlm.33.

18 M. Endriyo Susila et al, Buku Pedoman Penulisan Hukum, (Yogyakarta: Fakultas Hukum Universitas Muhammadiyah Yogyakarta, 2007), hlm. 40-41.

${ }^{19}$ Ginting, Yuni Priskila. "Holding Bumn Memerlukan Adanya Standar Prosedur Operasi Dalam Mencapai Aspek Tata Kelola Perusahaan Yang Baik. "Majalah
Undang-Undang Dasar Negara Republik Indonesia Pasal 33 ayat (2) mengamanatkan bahwa cabang-cabang produksi yang penting bagi negara dan yang menguasai hajat hidup orang banyak harus dikuasai oleh negara. BUMN diposisikan seperti koin mata uang, satu sisi berada pada rezim publik karena terdapat intervensi negara (pemerintah) di dalamnya dan pada sisi yang lain tunduk pada rezim privat (UU Perseroan Terbatas).

Dalam UU 19/2003 Tentang Badan Usaha Milik Negara. Pengertian BUMN sendiri adalah badan usaha yang seluruh atau sebagian besar modalnya dimiliki oleh negara melalui penyertaan secara langsung yang berasal dari kekayaan negara yang dipisahkan. ${ }^{20}$ Sedangkan Perusahaan Perseroan, yang selanjutnya disebut Persero adalah BUMN yang berbentuk perseroan terbatas yang modalnya terbagi dalam saham yang seluruh atau paling sedikit $51 \%$ (lima puluh satu persen) sahamnya dimiliki oleh Negara Republik Indonesia yang tujuan utamanya mengejar keuntungan. ${ }^{21}$

Perusahaan

perseroan (persero) merupakan badan usaha milik negara yang dibentuk bedasakan UU 9/1969 yang berbentuk Perseroan Terbatas yang seluruh atau paling sedikit 51 persen saham yang dikeluarkannya dimiliki oleh negara melalui penyertaan modal secara langsung, bahwa penyertaan modal negara ke dalam modal saham perseroan artinya negara menjadi penyetor dalam bentuk saham kepada BUMN.

Dalam sejarah di Indonesia perusahaan negara sebenarnya sudah dimulai sebelum masa kemerdekaan, yaitu sejak masa kolonial Belanda di Indonesia. Yang dimana Belanda mendirikan perusahaan yang nilainya strategis untuk kepentingan ekonomi yang di sebut dengan Vereenigde, Oostindische Compagnie (VOC). Berkaitan dengan hal tersebut, VOC melakukan penguasaan melalui banyak Unit Usaha yang dimlikinya seperti perusahaan Gemeenschaappelijke Mijnbouw Maatschaappij Billiton (GMB) untuk

Hukum Nasional50, No. 1 (2020): 1-18. DOI: https://doi.org/10.33331/mhn.v50i1.53

20 Republik Indonesia, Undang-Undang Nomor 19 Tahun 2003 Tentang Badan Usaha Milik Negara (Lembaran Negara Tahun 2003 Nomor 70, Tambahan Lembaran Negara Nomor 4297), pasal 1 angka 1

${ }^{21}$ Ibid, pasal 1 angka 2 
usaha timah, s'Lands Waterkracht Bedrijven (LB) untuk listrik, L.J.N. Eindhoven \& Co untuk penguasaan gas, Staats Spoorwegen (SS) untuk kereta api, KLM Interinsulair Bedrijf (KLM-IIB) untuk penerbangan, de Algemenevolks Crediet untuk kredit perbankan, pabrik gula, kilang minyak, kelapa sawit serta penguasaan bidangbidang strategis lainnya. ${ }^{22}$

Setelah Indonesia merdeka, Bung Karno melihat kondisi perekonomian masih lemah paska kemerdekaan, maka negara harus menguasai bidang usaha yang dapat menstimulasi kegiatan ekonomi sehingga Indonesia melakukan nasionalisasi seluruh perusahaan tersebut. ${ }^{23}$

Perusahaan-perusahaan milik negara yang ada di Indonesia saat ini sebagian besar memiliki akar sejarah di masa kolonial dan sebagian lagi di masa kemerdekaan. Sebagaian perusahaan yang didirikan masa kolonial yang telah dinasionalisasi diantaranya berada di bawah pengelolaan Kementerian BUMN. Lahirnya perusahaanperusahaa Hindia Belanda dimulai dari penyediaan lahan pada tahun 1870 yang diatur dalam Undang-Undang Agraria (Agrarische Wet) yang memberi kepastian hukum pertanahan di Hindia Belanda. Bagi pengusaha swasta berarti memberi kepastian untuk menggunakan lahan penduduk bumiputera, terutama melalui proses sewa lahan. Salah satunya aturan adalah hak erpacht yang memungkin para pengusaha untuk menyewa lahan dalam jangka waktu yang panjang sampai dengan 75 tahun. ${ }^{24}$

Ketika Indonesia merdeka dalam konteks ekonomi seperti dikepung aset-aset ekonomi perusahaan milik swasta yang berkembang pada kolonial selain asset milik pemerintah Hindia Belanda. Karena status kepemilikan berbeda maka proses peralihan kepemilikannya berbeda yaitu dari

22 Gunawan Nachrawi, BUMN Sebagai Usaha Pemerintah Menuju Kesejahteraan Rakyat, Tinjauan Filosopis,Sosiologis, Politik dan yuridis, Cendekia press, Bandung, 2021, Hal 43

${ }^{23}$ Rozik M. Kaelani, Landasan Hukum Dan Sejarah BUMN Di Indonesia, bulletin KAHMI FE Universitas Brawijaya, Edisi 1 Tahun 2007, dalam http://ketawanggede.tripod.com/edisi1.pdf.

24 Wasino. Sejarah nasionalisasi aset-aset BUMN : dari perusahaan kolonial menuju perusahaan nasional / Wasino ... [et al.]. Jakarta: Kementerian BUMN RI, 2014, hlm. 5 pemerintahan Hindia Belanda ke pemerintahan Indonesia dan nasionalisasi terhadap asset perusahaan swasta yang puncaknya adalah tahun $1957 .{ }^{25}$ Kalau dicermati dasar nasionalisasi tersebut berdasarkan landasan filosofis dan landasan sosiologis, UU 86/1958 yaitu: ${ }^{26}$

"bahwa tindakan yang telah diambil oleh Pemerintah terhadap perusahaan milik Belanda yang berada di dalam wilayah Republik Indonesia dalam rangka perjuangan pembebasan Irian Barat adalah sesuai dengan kebijaksanaan pembatalan K.M.B dan bahwa dalam taraf perjuangan pada masa ini dalam rangka pembatalan K.M.B dan perjuangan pembebasan Irian Barat tersebut di atas sudah tiba waktunya untuk mengeluarkan ketegasan terhadap perusahaan-perusahaan milik Belanda yang berada di dalam wilayah Republik Indonesia berupa nasionalisasi dari perusahaanperusahaan milik Belanda untuk dijadikan milik Negara".

Diterbitkannya UU No. 86 Tahun 1958 itu menjelaskan perusahaan-perusahaan milik Belanda yang berada di wilayah Republik Indonesia yang akan ditetapkan dengan Peraturan Pemerintah dikenakan nasionalisasi dan dinyatakan menjadi milik penuh dan bebas Negara Republik Indonesia. ${ }^{27}$

Berdasarkan hal tersebut Pemerintah Republik Indonesia membentuk badan usaha/korporasi yang di kuasai oleh negara/perusahaan negara yang berasal dari nasionalisasi perusahaan-perusahaan asing yang kemudian bertranformasi menjadi perusahaan negara. Ketika begawan ekonomi Indonesia, Sumitro Djojohadikusumo yang sepaham dengan pemikiran Muh. Hatta tentang ekonomi kerakyatan yang dapat dilihat dari disertasinya yang berjudul Het Volkscredietwezen in de Depressie atau Kredit Rakyat di Masa Depresi. Sumitro menyumbangkan pemikirannya dalam dua buku yakni buku Perkembangan

\footnotetext{
${ }^{25}$ Ibid, hlm. 6

26 Republik Indonesia, Undang-Undang Nomor 86 Tahun 1958 Tentang Nasionalisasi PerusahaanPerusahan Milik Belanda (Lembaran Negara Tahun 1958 Nomor 162)

27 Ibid, pasal 1
} 
pemikiran ekonomi: dasar teori ekonomi pertumbuhan dan ekonomi pembangunan, dan buku Kredit rakyat di masa depresi. Sumitro mengenyam pendidikan ekonomi dan mendapat gelar doktor dari Nederlandsche Economische Hogeschool di Rotterdam, Belanda, pada 1943. Selepas kuliah, Sumitro bekerja di lembaga riset Nederlandsche Economische Hogeschool lantaran kondisi perang saat itu tidak memungkinkan dirinya untuk kembali ke tanah air. Barulah pada 1946 Soemitro kembali ke Indonesia dan diamanahi menjadi staf Perdana Menteri Sutan Syahrir juga pernah menjadi Direktur Utama Banking Trading Center atau BTC yang memiliki pasar luar negeri, di bawah kepemimpinan Soemitro, BTC sempat menjadi kuasa usaha Republik Indonesia di Washington DC, Amerika Serikat. Di masa pemerintahan Orde Lama, Sumitro pernah ditunjuk sebagai Menteri Perdagangan dan Perindustrian pada 1950 hingga 1951, dan Menteri Keuangan pada 1952 hingga 1953 oleh Soekarno. Saat pemerintahan Presiden Soeharto. Kemudian Soemitro ditunjuk sebagai Menteri Perdagangan selama jangka waktu 1968 sampai 1972 dan Menteri Negara Riset pada 1972 hingga $1978 .^{28}$

Pada masa Soemitro kemudian memperjelas status perusahaan belanda yang dinasionalisasikan tersebut dengan diterbitkannya UU 9/1969. Usaha-usaha negara dalam bentuk perusahaan dibagi menjadi 3 (tiga) jenis yaitu pertama, Perusahaan Jawatan disingkat PERJAN adalah Perusahaan Negara yang didirikan dan diatur menurut ketentuan-ketentuan yang termaktub dalam Indonesische Bedrijvennwet (Stbl. 1927: 419 sebagaimana yang telah beberapa kali diubah dan ditambah). Kedua, Perusahaan Umum disingkat PERUM adalah Perusahaan Negara yang didirikan dan diatur berdasarkan ketentuan-ketentuan yang termaktub dalam Undang-Undang No. 19 Prp tahun 1960. Ketiga, Perusahaan Perseroan disingkat PERSERO adalah perusahaan dalam

28 S. Dian Andryanto, "Hari ini Kelahiran Sumitro Djojohadikusumo, Peletak Dasar Ekonomi Pembangunan", Sabtu, 29 Mei 2021 16:51 WIB, https://nasional.tempo.co/read/1466941/hari-inikelahiran-sumitro-djojohadikusumo-peletak-dasarekonomi-pembangunan (diakses tanggal 7 Agustus 2021, pukul 10.09 Wita) bentuk perseroan terbatas seperti diatur menurut ketentuan-ketentuan Kitab UndangUndang Hukum Dagang (Stbl. 1847: 23 sebagaimana yang telah beberapa kali diubah dan ditambah), baik yang saham-sahamnya untuk sebagiannya maupun seluruhnya dimiliki oleh Negara. ${ }^{29}$

Selain meneruskan BUMN sebagai warisan pemerintah Hindia Belanda, pemerintah Indonesia juga mendirikan BUMN berdasarkan ketentuan dalam Pasal 33 ayat (2) UUD 1945. Yang menyatakan bahwa "cabang-cabang produksi yang penting bagi negara dan yang menguasai hajat hidup orang banyak di kuasai oleh Negara". Atas dasar inilah sehingga didirikanlah BUMN diatur secara tersendiri, seperti bank-bank negara (BNI, BRI, BTN, Bank Mandiri), usaha jasa penerbangan Garuda, Pelayaran Nasional Indonesia (PELNI), pabrik semen seperti Semen Gresik, Semen Padang. Semen Kujang. Semen Cibinong, dan Semen Tonasa, serta pabrik pupuk, dan sebagainya.

Secara politik-ekonomi, pendirian BUMN di Indonesia dapat disederhanakan dengan mengemukakan tiga alasan pokok. Pertama, sebagai wadah bisnis aset yang dinasionalisasi, karena alasan ini terjadi di tahun 1950-an ketika pemerintah menasionalisasi perusahaan-perusahaan asing. Peristiwanya dimulai pada tahun 1957, ketika Kabinet Ali Satroamidjojo II jatuh disertai krisis ekonomi yang parah. Kejatuhan kabinet ini seakan memperkuat sinyal bahwa pemerintahan parlementer akan membawa Indonesia ke dalam keterpurukan.

Kedua, membangun industri yang diperlukan masyarakat, tetapi masyarakat sendiri (atau swasta) tidak mampu memasukinya, baik karena alasan investasi yang sangat besar maupun risiko usaha yang sangat besar. Pada pertengahan tahun 1960an, pemerintah mulai mendirikan pabrikpabrik pupuk urea, mulai di Sumatera Selatan, Jawa Barat, Kalimantan Timur, Jawa Timur, dan Aceh. Pemerintah mengambil alih Indosat sebagai home base pemilikan dan

29 Undang-Undang Republik Indonesia Nomor 9 Tahun 1969 Tentang Penetapan Peraturan Pemerintah Pengganti Undang-Undang No. 1 Tahun 1969 (Lembaran Negara Tahun 1969 NO. 16; Tambahan Lembaran Negara NO. 2890) Tentang Bentuk-Bentuk Usaha Negara Menjadi Undang-Undang, pasal 1 dan pasal 2 
pengelolaan Satelit Palapa Pemerintah juga mendirikan industri-industri kelistrikan sebagai bahan bakar energi nasional. Selain itu, pemerintah mendirikan industri pesawat terbang, IPTN, dengan tujuan menjadi pelaku bisnis regional di bidang pesawat angkut jenis menengah dan kecil.

Ketiga, membangun industri yang sangat strategis karena berkenaan dengan keamanan negara. Oleh karena itu, pemerintah membangun industri persenjataan (Pindad), bahan peledak (Dahana), pencetakan uang (Peruri), hingga pengelolaan stok pangan (Bulog). ${ }^{30}$

Pada masa itu, perusahaan negara diatur dengan berbagai peraturan perundangundangan seperti Undang-Undang Perusahaan Negara (Indonesiche Bedrijven Wet/BW), Undang-Undang Perbendaharaan Negara (Indonesische Comptabliteits Wet/ICW), dan Kitab Undang-Undang Hukum Perdata dan Hukum Dagang. Namun, segera disadari bahwa penggunaan Undang-Undang peninggalan Belanda tersebut tidak sepenuhnya dapat diterapkan. Oleh karena itu, perlu penyesuaian dengan alat alat produksi dan distribusi yang sesuai dengan Pasal 33 UUD 1945. Pemerintah kemudian mengeluarkan Peraturan Pemerintah Pengganti Undang-Undang Perpu, dahulu disebut juga Prp.) Nomor 19 Tahun 1960. Dengan Perpu ini, pengertian perusahaan negara diseragamkan yaitu semua perusahaan dalam bentuk apapun yang modalnya untuk seluruhnya merupakan kekayaan negara Republik Indonesia kecuali jika ditentukan lain berdasarkan undangundang.

Sejak tahun 1969, peranan BUMN dalam menunjang pembangunan nasional semakin meningkat sejalan dengan pelaksanaan pembangunan, namun pada masa orde baru kinerja BUMN sangat memprihatinkan. Kinerja perusahaan di nilai belum memadai, seperti tampak pada rendahnya laba yang di proleh di bandingkan dengan modal yang di tanamkan. ${ }^{31}$

Seiring dengan perkembangan yang ada, Pemerintah selanjutnya menerbitkan UU

30 Gunawan Nachrawi, Op. Cit., hal 44-45.

31 Republik Indonesia, Undang-undang Nomor 19 tahun 2003 tentang Badan Usaha Milik Negara, Penjelasan
19/2003 tentang Badan Usaha Milik Negara. Merujuk pada Undang-Undang ini khusunya dalam Bab X tentang Peralihan Pasal 93 di nyatakan bahwa dalam kurun waktu dua tahun terhitung sejak undang-undang ini mulai berlaku, semua BUMN yang berbentuk Perusahaan Jawatan harus sudah dirubah bentuknya menjadi Perusahan Umum (Perum) atau Perusahaan Perseroan (persero). ${ }^{32}$

BUMN dirancang untuk menciptakan pengelolaan dan pengawasan berlandaskan pada prinsip-prinsip efisiensi dan produktivitas guna meningkatkan kinerja dan nilai BUMN, serta menghindarkan BUMN dari tindakan-tindakan pengekspoitasian di luar asas tata kelola perusahaan yang baik. Undang-Undang ini juga dirancang untuk menata dan mempertegas peran lembaga dan posisi wakil pemerintah sebagai pemegang saham/pemilik modal BUMN serta mempertegas dan memperjelas hubungan BUMN selaku operator usaha dengan lembaga pemerintah sebagai regulator.

Sebagaimana telah diuraikan ditas Pasal 1 angka 1 Undang-Undang BUMN menjelaskan, bahwa "BUMN adalah badan usaha yang seluruh atau sebagian besar modalnya dimiliki oleh Negara melalui penyertaan secara langsung yang berasal dari kekayaan negara yang dipisahkan."

Selanjutnya, dalam ketentuan pasal 2 ayat (1) Undang-Undang BUMN menyatakan maksud dan tujuan pendirian BUMN di antaranya:

(a) Memberikan sumbangan bagi perkembangan perekonomian nasional padaumumnya dan penerimaan negara pada khususnya;

(b) Mengejar keuntungan;

(c) Menyelenggarakan kemanfaatan umum berupa penyediaan barang dan/atau jasa yang bermutu tinggi dan memadai bagi pemenuhan hajat hidup orang banyak;

(d) Menjadi perintis kegiatan-kegiatan usaha yang belum dapat dilaksanakan oleh sektor swasta dan koperasi;

(e) Turut aktif memberikan bimbingan dan bantuan kepada pengusaha golongan

32 Janah,Nur A.M. 2019. Makalah Perusahaan Jawatan. OSF Preprints. April 26. Doi:10.31219/osf.io/mycp7. 


ekonomi lemah, koperasi dan
masyarakat.
Jenis-jenis BUMN sebagaimana
berdasarkan Undang-Undang BUMN terbagi
atas 2 (dua) bentuk, yaitu:

(a) Perusahaan Perseroan (Persero)

Persero adalah BUMN yang berbentuk Perseroan Terbatas yang modalnya terbagi dalam saham yang seluruh atau paling sedikit $51 \%$ (lima puluh satu persen) sahamnya dimiliki oleh Negara Republik Indonesia dengan tujuan utamanya mengejar keuntungan. ${ }^{33}$ Maksud dan tujuan pendirian Persero yaitu $^{34}$ Menyediakan barang dan jasa yang bermutu tinggi dan berdaya saing kuat dan mengejar keuntungan semaksimal mungkin guna meningkatkan nilai perusahaan.

(b) Perusahaan Umum (Perum)

Perum adalah BUMN yang seluruh modalnya dimiliki oleh negara dan tidak terbagi atas saham, yang bertujuan untuk kemanfaatan umum berupa penyediaan barang dan/atau jasa yang bermutu tinggi sekaligus mengejar keuntungan berdasarkan prinsip pengelolaan perusahaan. ${ }^{35}$ Maksud dan tujuan pendirian Perum adalah menyelenggarakan usaha yang bertujuan untuk kemanfaatan umum berupa penyediaan barang dan jasa yang berkualitas dengan harga yang terjangkau oleh masyarakat berdasarkan prinsip-prinsip pengelolaan perusahaan yang sehat. ${ }^{36}$

Sedangkan gagasan pembentukan Badan Usaha Milik Daerah (BUMD) berangkat dari perspektif ideologi mengenai konsep negara hukum kesejahteraan yang timbul setelah abad 19. Di dalam ajaran dimaksud menekankan bahwa negara harus intervensi di dalam kehidupan sosial-ekonomi masyarakat untuk mensejahterakan warganya. Salah satu bentuk intervensi dimaksud melalui kewenangan membentuk Badan Usaha Milik Negara (BUMN) di pusat

\footnotetext{
${ }^{3}$ Log. Cit, pasal 1 angka 2

34 Ibid, pasal 12

35 Ibid, pasal 1 angka 4.

36 Republik Indonesia, Undang-Undang Nomor 19 Tahun 2003 Tentang Badan Usaha Milik Negara,pasal 36 ayat 1
}

maupun Badan Usaha Milik Daerah (BUMD) di daerah.

Sejarah BUMD tidak terlepas dari perkembangan kebijakan terkait dengan BUMN. Pada awalnya, BUMN adalah perusahaan-perusahaan negara baik yang berbentuk badan-badan berdasarkan hukum perdata maupun yang berbentuk badan hukum berdasarkan hukum publik antara lain yang berdasarkan Undang-Undang Perusahaan Indonesia. Kehadiran BUMD di Indonesia mempunyai latar belakang yang sama dengan BUMN, yakni terkait dengan nasionalisasi perusahaan-perusahaan milik Belanda di Indonesia. Pada tahun 1957 Presiden Soekarno mengumumkan penyatuan Irian Barat dengan Indonesia, karena Perserikatan Bangsa-bangsa (PBB) gagal mengeluarkan resolusi yang menghimbau agar Belanda mau berunding dengan Indonesia untuk masalah Irian Barat. Penyatuan Irian Barat tersebut menjadi titik awal nasionalisasi perusahaan-perusahaan milik Belanda yang beroperasi di Indonesia. ${ }^{37}$

Sejak itu, Pemerintah Pusat mendirikan berbagai perusahaan milik Negara (BUMN). Pemerintah Pusat juga mendorong Pemerintah Swatantra Tk I dan Tk II pada waktu itu (sekarang setingkat Provinsi dan Kabupaten) untuk mendirikan perusahaan milik Daerah guna mendorong percepatan pertumbuhan ekonomi dan meningkatkan jumlah produksi (berbagai barang dan jasa) yang waktu itu sangat dibutuhkan masyarakat. Perkembangan di tingkat Pusat direspons dengan antusias oleh Pemerintah Daerah Swatantra.

Istilah Badan Usaha Milik Daerah (BUMD) yang mengemuka selama ini tidak terlepas dari kehadiran Undang-Undang No. 5 Tahun 1962 tentang Perusahaan Daerah, akan tetapi pada undang-undang tersebut tidak satupun ditemukan istilah Badan Usaha Milik Daerah. Pada Pasal 2 undang-undang tersebut memberi penjelasan tentang Perusahaan Daerah adalah "Perusahaan Daerah ialah semua perusahaan yang didirikan berdasarkan Undang-Undang ini yang modalnya untuk seluruhnya atau untuk sebagian merupakan kekayaan daerah yang

37 Riris Prasetyo, Sejarah BUMD, diakses https://asetdaerah.wordpress.com/2011/07/15/sejarahbumd/. Pada tanggal 15 juli 2021 pukul 23:14 WIB. 
dipisahkan, kecuali jika ditentukan lain dengan atau berdasarkan Undang-Undang". Pasal tersebut sama sekali tidak menunjukkan apakah perusahaan daerah merupakan BUMD, walaupun pada pasal tersebut memperlihatkan ciri perusahaan daerah merupakan badan hukum dengan harta yang terpisah ${ }^{38}$. Selain itu ketidak jelasan pengertian perusahaan pada konsep perusahaan daerah menyebabkan perusahaan daerah kesulitan dalam menjalankan fungsi, pengelolaan dan pengembangannya.

Undang-Undang Nomor 5 tahun 1962 tentang Perusahaan Daerah merupakan undang-undang yang penyusunannya diawali dari terbitnya Perpu Nomor 17 Tahun 1960 tentang Perusahaan Negara. Berdasarkan UU 5/1962 tentang Perusahaan Daerah, Perusahaan Daerah adalah perusahaan yang seluruh atau sebagian besar modalnya berasal dari kekayaan daerah yang dipisahkan. Mengingat bahwa pembinaan Pemerintahan Daerah berada di bawah tanggung jawab Menteri Dalam Negeri, maka peraturan pelaksana UU 5/1962 tentang Perusahaan Daerah diterbitkan oleh Menteri Dalam Negeri baik berupa Peraturan Menteri Dalam Negeri seperti Peraturan Menteri Dalam Negeri 1 Tahun 1984 tentang Tata Cara Pembinaan dan Pengawasan Perusahaan Daerah, Peraturan Menteri Dalam Negeri Nomor 3 Tahun 1990 tentang Pengelolaan Barang Milik Perusahaan Daerah. ${ }^{39}$

Perusahaan daerah merupakan salah satu bentuk usaha dimana pada hakikatnya merupakan cerminan Daerah dalam mengembangkan potensi-potensi yang ada di Daerah, atau marwah dari Pasal 33 dan Pasal 18 UUD NRI 1945 jo Pasal 177 UndangUndang No. 32 Tahun 2004 tentang Pemerintahan Daerah.

Seiring perkembangan semangat otonomi daerah lahir Undang-Undang Nomor

\footnotetext{
38 Republik Indonesia, Undang-Undang Nomor 5 Tahun 1962 Tentang Perusahaan Daerah (Lembaran Negara Tahun 1962 Nomor 10, Tambahan Lembaran Negara Nomor 2387), penjelasan pasal 2

39 Yudho Taruno Muryoto, "Implikasi Yuridis Diundangkannya Undang-Undang Nomor 23 Tahun 2014 Tentang Pemerintah Daerah Terhadap Pengaturan Badan Usaha Milik Daerah Di Indonesia, "yustisia, Edisi 90, September- Desember 2014, hal.130.
}

23 Tahun 2014 (UU 23/2014) tentang Pemerintahan Daerah yang disahkan pada tanggal 30 September 2014 dan diundangkan pada tanggal 2 Oktober 2014, memberikan implikasi secara yuridis terhadap pengaturan BUMD yang selama ini telah ada di Indonesia. Jika dicermati pada Undang-Undang Pemerintahan Daerah ini, secara khusus mengatur berkenaan dengan BUMD pada BAB XII terdiri dari 12 Pasal, dimulai dari Pasal 331 sampai dengan Pasal 343 serta tersebar dibeberapa pasal, seperti BAB I Ketentuan Umum Pasal 1 angka 40, yang memberikan pengertian tentang BUMD, serta beberapa pasal yang menjadi sangat penting dicermati terkait dengan keberadaan BUMD, seperti Pasal 134 ayat (1) huruf c, 188 ayat (1) huruf c, 298 ayat (5) huruf c, 304 ayat (1) dan (2), 320 ayat (2) huruf g, 402 ayat (2), 405 dan Pasal 409. Dengan diundangkannya Undang-Undang Pemerintahan Daerah sesuai dengan Pasal 409 dengan tegas menyatakan bahwa: Dengan berlakunya Undang-Undang Republik Indonesia Nomor 23 Tahun 2014 Tentang Pemerintahan Daerah (Lembaran Negara Republik Indonesia Tahun 2014 Nomor 244 Tambahan Lembaran Negara Republik Indonesia Nomor 5587); mencabut dan menyatakan tidak berlaku: ${ }^{40}$

(a) Undang-Undang Nomor 5 Tahun 1962 tentang Perusahaan Daerah (Lembaran Negara Republik Indonesia Tahun 1962 Nomor 10, Tambahan Lembaran Negara Republik Indonesia Nomor 2387);

(b) Undang-Undang Nomor 32 Tahun 2004 tentang Pemerintahan Daerah (Lembaran Negara Republik IndonesiaTahun 2004 Nomor 125, Tambahan Lembaran Negara Republik Indonesia Nomor 4437) sebagaimana telah diubah beberapa kali terakhir dengan Undang-Undang Nomor 12 Tahun 2008 tentang Perubahan Kedua Atas Undang- Undang Nomor 32 Tahun 2004 tentang Pemerintahan Daerah (Lembaran Negara Republik Indonesia Tahun 2008 Nomor 59, Tambahan Lembaran Negara Republik Indonesia Nomor 4844)

40 Republik Indonesia, Undang-Undang Nomor 23 Tahun 2014 Tentang Pemerintahan Daerah, Pasal 409. 
Akan tetapi dengan masih sangat barunya keberadaan UU 23/2014, belum dilengkapi dengan peraturan pelaksanaan, sehingga masih dapat digunakan/diberlakukan semua ketentuan peraturan perundang-undangan yang merupakan peraturan pelaksanaan dari UU 5/1962 tentang Perusahaan Daerah, sepanjang tidak bertentang dengan undangundang baru tersebut (Pasal 405), serta undang-undang mengamanatkan bahwa paling lama 2 (dua) tahun sejak diundangkan, peraturan pelaksanaannya harus sudah ditetapkan (Pasal 410). Pada UU 23/2014 telah memberikan pengertian BUMD secara tegas, sebagaimana diatur dalam Pasal 1 angka 40 UU 23/2014 memberi pengertian bahwa BUMD adalah badan usaha yang seluruh atau sebagian besar modalnya dimiliki oleh daerah. Jika mencermati pasalpasal pada BAB XII, memberikan penegasanpenegasan diantaranya terdapat pada pasal 331 yang menegasakan bahwa daerah dapat mendirikan BUMD, yang dimana pendirian BUMD itu di tetapkan Dengan Perda, dan terdiri dari atas Perusahaan Umum Daerah Dan Perusahaan Perseroan Daerah. ${ }^{41}$

\section{Kedudukan Badan Usaha Milik Desa (BUMDes) Pada Masa Otonomi Daerah}

Istilah Badan Usaha yang ada di Desa telah ada semenjak lahirnya semangat otonomi daerah yang di tandai dengan di sahkannya undang-Undang Nomor 22 Tahun 1999 Tentang Pemerintah Daerah. UndangUndang ini mendorong desa untuk mendirikan suata badan usaha yang sesuai dengan kebutuhan masyarakat desa. Sebagaimana dalam pasal 108 UU 22/1999 tentang pemerintah daerah di bagian kelima tentang keuangan desa yang yang mengatakan bahwa "desa dapat memiliki badan usaha sesuai dengan peraturan perundang-undangan". Dan dalam pasal 107 ayat (1) terkait pendapatan asli desa yang salah satunya bersumber dari hasil usaha desa, hasil kekayaan desa, hasil swadaya dan partisipasi, hasil gotong royong dan lain-lain pendapatan yang sah. Ini menandakan bahwa undang-undang ini mendorong desa untuk melakukan pemberdayaan terhadap potensi desa dalam rangka meningkatkan

${ }^{41}$ Ibid. 130 pendapatan desa yang di lakukan dengan pendirian Badan Usaha Milik Desa, kerja sama dengan pihak ketiga, dan kewenangan melakukan pinjaman. ${ }^{42}$

Seiring waktu berjalan dengan lahirnya Undang-undang Nomor 32 Tahun 2004 tentang pemerintah Daerah yang merupakan hasil revisi atas UU 22/1999 tentang Pemerintahan Daerah. Memberikan landasan hukum terkait BUMDes sebagaimana dalam pasal 213 Ayat 1 yang menyatakan, bahwa "Desa dapat mendirikan badan usaha milik desa sesuai dengan kebutuhan dan potensi desa. ${ }^{43}$ Selain itu juga diatur dalam Peraturan Pemerintah Nomor 72 Tahun 2005 tentang Desa, yang didalamnya mengatur tentang BUMDes, yaitu pada Pasal 78-81, Bagian Kelima tentang Badan Usaha Milik Desa, sebagai mana dinyatakan di bawah ini: ${ }^{44}$

Pasal 78.

(1) Dalam meningkatkan pendapatan masyarakat dan Desa, Pemerintah Desa dapat mendirikan Badan Usaha Milik Desa sesuai dengan kebutuhan dan potensi Desa.

(2) Pembentukan Badan Usaha Milik Desa sebagaimana dimaksud pada ayat (1) ditetapkan dengan Peraturan Desa berpedoman pada peraturan perundangundangan.

(3) Bentuk Badan Usaha Milik Desa sebagaimana dimaksud pada ayat (1) harus berbadan hukum.

Pasal 79

(1) Badan Usaha Milik Desa sebagaimana dimaksud dalam Pasal 78 ayat (1) adalah usaha desa yang dikelola oleh Pemerintah Desa.

(2) Permodalan Badan Usaha Milik Desa dapat berasal dari :
a. Pemerintah desa
b. Tabungan masyarakat
c. bantuan Pemerintah, Pemerintah Provinsi dan Pemerintah Kabupaten/Kota;
d. pinjaman dan/atau
e. penyertaan modal pihak lain atau kerja sama bagi hasil atau dasar saling menguntungkan.


(3) Kepengurusan Badan Usaha Milik Desa terdiri dari Pemerintah Desa dan masyarakat.

Pasal 80

(1) Badan Usaha Milik Desa dapat melakukan pinjaman sesuai dengan peraturan perundang-undangan.

(2) Pinjaman sebagaimana dimaksud pada ayat (1) dilakukan setelah mendapat persetujuan BPD.

Pasal 81

(1) Ketentuan lebih lanjut mengenai Tata Cara Pembentukan dan Pengelolaan Badan Usaha Milik Desa diatur dengan Peraturan Daerah Kabupaten/Kota.

(2) Peraturan Daerah Kabupaten/Kota sebagaimana dimaksud pada ayat (1) sekurang-kurangnya memuat :
a. Bentuk badan hukum
b. kepengurusan
c. hak dan kewajiban
d. permodalan
e. bagi hasil usaha
f. kerja sama dengan pihak ketiga
g. mekanisme pengelolaan dan pertanggung jawaban.

Namun menurut praturan perundangundangan ini baik UU 32/2004 Tentang Pemerintah Daerah dan PP 72/2005 Tentang desa. Belum di atur secara terprinci mengenai bumdes termasuk tidak di jelaskan secara terprinci mengenai proses pendirian BUMDes, siapa saja yang berhak mengelola BUMDes, sumber permodalan BUMDes yang belum Jelas, jenis usaha yang diperbolehkan dan pelaporannya pertanggung jawaban BUMDes itu sendiri belum diatur secara rinci dalam undang-undang ini.

Pemerintah berharap bahwa BUMDes ini diharapkan mampu menstimulasi dan menggerakkan roda perekonomian di pedesaan. Aset ekonomi yang ada di desa harus dikelola sepenuhnya oleh masyarakat desa. Substansi dan filosofi BUMDes harus dijiwai dengan semangat kebersamaan sebagai upaya memperkuat aspek ekonomi kelembagaannya. seiring waktu berjalan pemerintah mengeluarkan landasan hukum lagi terkait BUMDes yang lebih rinci yang kali ini lewat Permendagri No. 39 Tahun 2010 tentang Badan Usaha Milik Desa. Yang di mana dalam Permendagri ini khusus berbicara BUMDes yang terdiri dari Tujuh BAB dan 25 pasal. Yang di atur di antaranya terkait Pembentukan BUMDes. Pengelolaan BUMDes, pembinaan sampai ke pengawasan BUMDes itu sendiri. ${ }^{45}$ Dengan demikian eksistensi BUMDes sebagai lembaga ekonomi sudah diakui sejak tahun 2004, namun peraturan perundangan yang membahas lebih rinci tentang Bumdes baru tersedia pada tahun 2014 dengan lahirnya semangat otonomi desa dengan lahirnya UU Desa. Yang memberikan hak, kewajiban dan kewenangan seluas-luasnya kepada desa untuk mengatur urusan desanya sendiri tak terkecuali BUMDes itu sendiri.

Pasal 1 angka 6 UU Desa menyebutkan BUMDes adalah badan usaha yang seluruh atau sebagian besar modalnya dimiliki oleh desa melalui penyertaan secara langsung yang berasal dari kekayaan desa yang dipisahkan guna mengelola aset, jasa pelayanan, dan usaha lainnya untuk sebesarbesarnya kesejahteraan masyarakat desa dan Pasal 87 ayat (1) UU Desa menyebutkan desa dapat mendirikan Badan Usaha Milik Desa yang disebut BUM Desa. Dalam 2 Pasal tersebut, tidak dijelaskan secara khusus bentuk badan usaha dari BUMDes.

UU Desa aturan pelaksanaannya yaitu PP 43/2014 Tentang Desa (PP Desa) juga disebutkan bahwa BUMDes, yang selanjutnya disebut BUMDes, adalah badan usaha yang seluruh atau sebagian besar modalnya dimiliki oleh Desa melalui penyertaan secara langsung yang berasal dari kekayaan Desa yang dipisahkan guna mengelola aset, jasa pelayanan, dan usaha lainnya untuk sebesarbesarnya kesejahteraan masyarakat Desa. ${ }^{46}$

Selanjutnya dalam Bab X Pasal 87 UU Desa diatur bahwa: (1) desa dapat mendirikan Badan Usaha Milik Desa yang disebut BUM Desa; (2) BUM Desa dikelola dengan semangat kekeluargaan dan kegotongroyongan; (3) BUM Desa dapat menjalankan usaha di bidang ekonomi dan/atau pelayanan umum sesuai dengan ketentuan peraturan perundang-undangan. ${ }^{47}$

\footnotetext{
45 Republik Indonesia, Peraturan Menteri Dalam Negeri Nomor 39 Tahun 2010 Tentang Badan Usaha Milik Desa.

46 Republik Indonesia, Peraturan Pemerintah Nomor 43 tahun 2014 Tentang Desa.

47 Republik Indonesia, Undang-Undang Nomer 6 Tahun 2014 Tentang Desa, Pasal 87.
} 
Pada pasal 88 UU Desa jo. Pasal 132 PP Desa disebutkan bahwa BUMdes didirikan berdasarkan musyawarah desa yang kemudian hasil musyawarah tersebut ditetapkan dengan Peraturan Desa. Selanjutnya dalam Pasal 135 PP Desa disebutkan bahwa modal awal Bumdes bersumber dari APBDesa yang merupakan kekayaan Desa yang dipisahkan dan tidak terbagi atas saham. Modal Bumdes terdiri dari: 1) Penyertaan Modal Desa, yang berasal dari APB Desa dan lainnya; 2) Penyertaan Modal Masyarakat Desa. ${ }^{48}$

BUMDes terlebih dahulu dikukuhkan melalui Undang-Undang, namun sebagai badan hukum, ia harus memiliki organisasi yang teratur. Organisasi yang teratur ini dapat dilihat dalam Pasal 132 PP Desa yang menyebutkan bahwa Pengelola BUMDes setidaknya harus terdiri dari: 1) Penasehat; dan 2) Pelaksana Operasional. Penasehat secara ex-officio dijabat oleh Kepala Desa, sedangkan Pelaksana Operasional adalah perseorangan yang diangkat dan diberhentikan oleh Kepala Desa.

Secara historis, pada awalnya BUMDes diatur sebagai badan hukum. Ini dapat dilihat dalam penjelasan Pasal 213 ayat (2) UU 32/2004 tentang Pemerintah Daerah yaitu Badan Usaha Milik Desa adalah badan hukum sebagaimana diatur dalam peraturan perundang-undangan dan ditegaskan kembali dalam Pasal 78 ayat (3) PP 72/2005 tentang Desa yaitu Bentuk Badan Usaha Milik Desa sebagaimana dimaksud pada ayat (1) harus berbadan hukum.

Sekitar 10 tahun kemudian, dengan disahkannya UU Desa bentuk badan usaha BUMDes berubah. Di dalam Pasal 1 angka 6 UU Desa, disebutkan BUMDes adalah badan usaha dan dalam penjelasannya di Pasal 87 ayat (1) BUMDesa merupakan suatu badan usaha bercirikan desa yang secara spesifik tidak bisa disamakan dengan badan hukum seperti perseroan terbatas, CV atau koperasi. Yang membuat BUMDes menjadi bentuk badan usaha berbadan hukum yang baru. Berbeda dengan BUMN dan BUMD yang dalam peraturan perundang-undangan telah jelas diatur dapat berbentuk perseroan terbatas maupun perseroan umum..

\footnotetext{
48 Log. Cit, Pasal 132 dan 135
}

Dari beberapa aturan tersebut di atas terlihat bahwa Bumdes memang dibentuk dengan konsep sebagai badan hukum. Untuk dapat disebut sebagai badan hukum, maka harus memiliki karakteristik antara lain yaitu: 1) Adanya harta kekayaan yang terpisah; 2) Mempunyai tujuan tertentu; 3) Mempunyai kepentingan sendiri; 4) Adanya organisasi yang teratur. Keempat ciri tersebut tercermin dalam ketentuan yang mengatur tentang BUMDes tersebut. Kekayaan BUMDes merupakan kekayaan Desa yang dipisahkan. BUMDes juga memiliki tujuan dan kepentingan yang ditetapkan oleh UndangUndang yaitu untuk mengembangkan perekonomian desa dan meningkatkan pendapatan desa. BUMDes juga memiliki organisasi yang teratur yang dapat dilihat dari adanya penasehat dan pelakasana operasional. ${ }^{49}$

Secara karakteristik, BUMDes telah dapat dikategorikan sebagai badan usaha berbadan hukum karena telah memenuhi karakteristik sebagai berikut:

(1) adanya kekayaan yang terpisah

Pasal 135 ayat (3) Peraturan Pemerintah Republik Indonesia Nomor 47 Tahun 2015 Tentang Perubahan Atas Peraturan Pemerintah Nomor 43 Tahun 2014 menyebutkan bahwa kekayaan BUMDes yang bersumber dari penyertaan modal desa merupakan kekayaandesa yang dipisahkan.

(2) Mempunyai tujuan tertentu

Penjelasan Pasal 87 ayat (1) UU Desa menyebutkan bahwa BUMDes dibentuk untuk mendayagunakan segala potensi ekonomi, kelembagaan perekonomian, serta potensi sumber daya alam dan sumber daya manusia dalam rangka meningkatkan kesejahteraan masyarakat desa

(3) Mempunyai kepentingan sendiri

Kepentingan BUMDes terdapat juga dalam Penjelasan Pasal 87 ayat (1) UU Desa menyebutkan bahwa BUMDes berorientasi kepada keuntungan

49 Erni Herawati, 2016, Badan Usaha Milik Desa, Status dan Pembentukannya, Bina Nusantara (online) https://businesslaw.binus.ac.id/2016/10/16/badan-usaha-milikdesa-status-dan-pembentukannya/\#, (26 juli 2021, jam 22:45) 
keuangan dan mendukung peningkatan kesejahteraan masyarakat.

(4) Adanya organisasi yang teratur

Organisasi BUMDes terpisah dari organisasi pemerintah desa dan organisasi BUMDes paling sedikit terdiri atas penasihat serta pelaksana operasional. Ketetuan ini di atur dalam Pasal 132 ayat (3) dan (4) PP 43/2014.

Namun dengan dengan keterangan di atas baik menurut UU Desa dan PP Desa ini Status BUMDes sebagai Badan Usaha Berbadan Hukum menjadi sebuah permasalahan dan perdebatan yang sering muncul di masyarakat. Hal ini menimbulkan permasalahan ketika BUMDes ingin bekerja sama dengan pihak ketiga ataupun dari indepedensi BUMDes itu sendiri karna tidak ada regulasi yang secara tegas menyatakan BUMDes sebagai Badan Hukum.

Dalam PP desa pasal 142 Menyebutkan Ketentuan lebih lanjut mengenai pendirian, pengurusan dan pengelolaan, serta pembubaran BUM Desa diatur dengan Peraturan Menteri. Sedangkan Peraturan Menteri Desa, Pembangunan Daerah Tertinggal, dan Transmigrasi Nomor 4 Tahun 2015 Tentang Pendirian, Pengurusan dan Pengelolaan dan Pembubaran Badan Usaha Milik Desa menyatakan bahwa Badan Usaha Milik Desa, yang selanjutnya disebut BUMDes adalah badan usaha yang seluruh atau sebagian besar modalnya dimiliki oleh desa melalui penyertaan secara langsung yang berasal dari kekayaan desa yang dipisahkan guna mengelola aset, jasa pelayanan dan usaha lainnya untuk sebesar besarnya kesejahteraan masyarakat desa. BUMDes adalah badan usaha yang sebagian besar modalnya dimiliki oleh desa melalui penyertaan secara langsung yang berasal dari kekayaan desa guna mengolah aset, jasa pelayanan dan usahausaha lainya untuk pembangunan dan kesejahteraan masyarakat desa. BUMDes merupakan lembaga yang terdapat interaksi ekonomi antara pemerintahan desa dengan masyarakat desa. Tujuannya adalah untuk mengurangi angka kemiskinan dan akan mengangkat keluarga yang tidak mampu menjadi keluarga yang sejahtera. BUMDes ini juga berfungsi sebagai lembaga sosial dan komersial yang diharapkan mampu menjadi motor penggerak ekonomi di desa. BUMDesa sebagai lembaga sosial diharuskan berpihak kepada kepentingan masyarakat. Sedangkan BUMDes sebagai lembaga komersial bertujuan mencari keuntungan untuk meningkatkan pendapatan desa. ${ }^{50}$

\section{Kebijakan BUMDes Paska Berlakunya Undang-Undang Nomor 11 Tahun 2020 Tentang Cipta Keja.}

Undang-Undang Nomor 11 Tahun 2020 Tentang Cipta Kerja atau yang selanjutnya disebut UU Cipta Kerja dalam pasal 1 angka 1 menjelelaskan mengenai definisi Cipta Kerja yaitu upaya penciptaan kerja melalui usaha kemudahan, perlindungan, dan pemberdayaan koperasi dan usaha mikro, kecil, dan menengah, peningkatan ekosistem investasi dan kemudahan berusaha, dan investasi Pemerintah Pusat dan percepatan proyek strategis nasional. ${ }^{51}$

Tujuan diundangkannya UU Cipta Kerja adalah sebagaimana dimuat di dalam bagian konsiderannya. UU Cipta Kerja diharapkan mampu menyerap tenaga kerja Indonesia yang seluas-luasnya di tengah persaingan yang semakin kompetitif dan tuntutan globalisasi ekonomi. Pengaturan yang berkaitan dengan kemudahan, perlindungan, dan pemberdayaan koperasi dan usaha mikro, kecil, dan menengah, peningkatan ekosistem investasi, dan percepatan proyek strategis nasional, termasuk peningkatan perlindungan dan kesejahteraan pekerja yang tersebar di berbagai Undang-Undang sektor saat ini belum dapat memenuhi kebutuhan hukum untuk percepatan cipta kerja sehingga perlu dilakukan perubahan. ${ }^{52}$

Adapun landasan filosofis diundangkannya UU Cipta Kerja adalah didasarkan pada Pasal 4, Pasal 5 ayat (1), Pasal 18, Pasal 18A, Pasal 18B, Pasal 20, Pasal 22D ayat (2), Pasal 27 ayat (2), Pasal 28D ayat (1) dan ayat (2), dan Pasal 33 Undang-Undang Dasar Negara Republik Indonesia Tahun 1945.

50 Maryunani, Pembanguanan Bumdes dan Pemberdayaan Pemerintah Desa, (Bandung;CV Pustaka Setia,2007), hlm. 31.

51 Republik Indonesia, Undang-undang Nomor 11 Tahun 2020 Tentang Cipta Kerja, Pasal 1 Angka 1

52 Alfiansyah, Setatus Badan Usaha Milik Desa Sebagai Badan Hukum Atas Di Undangkannya Undang-Undang Cipta Kerja, Jurnal Ilmu Sosial dan Pendidikan, Vol. 5, No. 1, (Maret 2021), hal. 216 
Terdapat pengaturan mengenai BUMDes dalam UU Ciptaker sebagaimana diatur dalam Pasal 117 UU Cipta Kerja yang mengubah ketentuan dalam Undang-Undang Nomor 6 Tahun 2014 tentang Desa Pasal 1 angka 6 Badan Usaha Milik Desa, yang selanjutnya disebut BUM Desa, adalah Badan Hukum yang didirikan oleh desa dan/atau bersama desa-desa guna mengelola usaha, memanfaatkan aset, mengembangkan investasi dan produktivitas, menyediakan jasa pelayanan, dan/atau menyediakan jenis usaha lainnya untuk sebesar-besarnya kesejahteraan masyarakat Desa.

Serta Ketentuan Pasal 87 yang juga mengatur tentang BUMDes diubah dalam UU Cipta Kerja dalam pasal 117 sehingga berbunyi sebagai berikut: ${ }^{53}$

Pasal 87

(1) Desa dapat mendirikan BUM Desa

(2) BUM Desa sebagaimana dimaksud pada ayat (1) dikelola dengan semangat kekeluargaan dan kegotongroyongan

(3) BUM Desa dapat menjalankan usaha di bidang ekonomi dan/atau pelayanan umum sesuai dengan ketentuan peraturan perundang-undangan.

(4) BUM Desa sebagaimana dimaksud pada ayat (1) dapat membentuk unit usaha berbadan hukum sesuai dengan kebutuhan dan tujuan

(5) Ketentuan lebih lanjut mengenai BUM Desa sebagaimana dimaksud pada ayat (1), ayat (2), ayat (3), dan ayat (4) diatur dengan Peraturan Pemerintah

Penjelasan Pasal 117 ayat (1) UU Cipta Kerja yang mengubah ketentuan dalam Pasal 87 UU Desa menjelaskan bahwa BUMDes dibentuk oleh Pemerintah Desa untuk mendayagunakan segala potensi ekonomi, kelembagaan perekonomian, serta potensi sumber daya alam dan sumber daya manusia dalam rangka meningkatkan kesejahteraan masyarakat Desa. BUMDes secara spesifik tidak dapat disamakan dengan badan hukum seperti perseroan terbatas, atau koperasi. Oleh karena itu, BUMDes merupakan suatu badan usaha bercirikan Desa yang dalam pelaksanaan kegiatannya di samping untuk membantu penyelenggaraan Pemerintahan Desa, juga untuk memenuhi kebutuhan masyarakat Desa. BUMDes juga dapat

\footnotetext{
53 Ibid, hlm.683
}

melaksanakan fungsi pelayanan jasa, perdagangan, dan pengembangan ekonomi lainnya.

Dalam meningkatkan sumber pendapatan Desa, BUMDes dapat menghimpun tabungan dalam skala lokal masyarakat Desa, antara lain melalui pengelolaan dana bergulir dan simpan pinjam. BUM Desa dalam kegiatannya tidak hanya berorientasi pada keuntungan keuangan, tetapi juga berorientasi untuk mendukung peningkatan kesejahteraan masyarakat Desa. BUM Desa diharapkan dapat mengembangkan unit usaha dalam mendayagunakan potensi ekonomi. Dalam hal kegiatan usaha dapat berjalan dan berkembang dengan baik, sangat dimungkinkan pada saatnya BUM Desa mengikuti badan hukum yang telah ditetapkan dalam ketentuan peraturan perundang-undangan.

Posisi BUMDes setelah UU Cipta Kerja sebagai Badan Hukum Entitas Baru yang kedudukannya setara dengan Perseroan Terbatas (PT) setara dengan BUMN pada level nasional dan BUMD pada level daerah sebagaimana dijelaskan dalam Penjelasan Pasal 117 UU Cipta Kerja yang mengubah Pasal 87 UU Desa bahwa Posisi BUMDes sebagai badan hukum tidak dapat dipersamakan dengan Perseroan dan Koperasi. Adapun Dampak Positif yang diharapkan atas status BUMDes sebagai badan Hukum diantaranya adalah mempermudah kemitraan desa, mempermudah mempromosikan potensi daerah, mempercepat perbaikan ekonomi daerah melalui desa dan mempercepat keberhasilan Sustainable Development Goals (SDGs) Nasional.

\section{a. Mekanisme Pembentukan BUM Desa/BUM Desa Bersama}

Pemerintah telah mengeluarkan Peraturan Pemerintah Nomor 11 Tahun 2021 Tentang Badan Usaha Milik Desa atau yang selanjutnya di sebut dengan PP BUM Desa, merupakan aturan pelaksana dari pasal 117 dan pasal 185 huruf b UU Cipta Kerja, perlu menetapkan praturan Pemerintah Tentang Badan Usaha Milik Desa. Bumdes yang selama ini kita kenal dalam aturan Perundang-undangan disebut dengan BUM Desa. Badan Usaha Milik Desa dalam 
ketentuan umum PP BUM Desa atau BUMDES adalah badan hukum yang didirikan oleh desa dan/atau bersama desa-desa guna mengelola usaha, memanfaatkan aset, mengembangkan investasi dan produktivitas, menyediakan jasa pelayanan, dan/atau menyediakan jenis usaha lainnya untuk sebesar-besarnya kesejahteraan masyarakat Desa. ${ }^{54}$

Dalam PP BUM Desa ini terkait mekanisme pembentukan BUM Desa/ BUM Desa Bersama yang berupaya mengelola usaha, memapaatkan asset, mengembangkan investasi dan produktivitas, menyediakan jasa pelayanan atau usaha lainnya dalam rangka meningkatkan kesejahteraan masyarakat desa. Secara spesifik, pendirian BUMDes adalah untuk menyerap tenaga kerja desa meningkatkan kreatifitas dan peluang usaha ekonomi produktif mereka yang berpenghasilan rendah. Sasaran pemberdayaan ekonomi masyarakat desa melalui BUMDes ini adalah untuk melayani masyarakat desa dalam mengembangkan usaha produktif.

Adapun tujuan yang ingin dicapai dengan pendirian BUM Desa/ BUM Desa Bersama dalam konteks pembangunan desa seperti yang di sebutkan dalam pasal 3 dalam PP BUMDes yaitu

(1) melakukan kegiatan usaha ekonomi melalui pengelolaan usaha, serta pengembangan investasi dan procluktivitas perekonomian, dan potensi Desa;

(2) melakukan kegiatan pelayanan urnum melalui persediaan barang dan atau jasa serta pemenuhan kebutuhan umurn masyarakat Desa, dan mengelola lumbung pangan Desa;

(3) memperoleh keuntungan atau laba bersih bagi peningkatan pendapatan asli Desa serta mengembangkan sebesarbesarrnya manfaat atas surnber daya ekonomi masyarakat Desa

(4) permanfaatan Aset Desa guna menciptakan nilai tambah atas Aset Desa; dan

(5) mengembangkan ekosistem ekonomi digital di desa

Dalam mewujudkan tujuan yang di sebutkan diatas, pengelolaannya harus

54 Republik Indonesia, Peraturan Pemerintah Nomor 11 Tahun 2021 Tentang Badan Usaha Milik Desa dilaksanakan berdasarkan semangat kekeluargaan dan kegotong royongan dengan prinsip sebagai mana dalam pasal 4 PP BUMDes yaitu dengan prinsip, professional, terbuka dan bertanggung jawab, partisipatif, prioritas sumber daya lokal dan berkelanjutan.

Pendirian BUM Desa/BUM Desa Bersama di sepakati melalui Musyawarah Desa, sebagai mana di atur dalam PP BUM Desa sebagai berikut:

Pasal 7

(1) BUM Desa didirikan oleh 1 (satu) desa berdasarkan Musyawarah Desa dan pendiriannya ditetapkan dengan Peraturan Desa.

(2) BUM Desa bersama diclirikan oleh 2 (dua) Desa atau lebih berdasarkan musyawarah Antar Desa dan pendiriannya ditetapkan dengan Peraturan Bersama Kepala Desa.

(3) BUM Desa bersama didirikan berdasarkan kesamaan potensi, kegiatan usaha, atau kedekatan wilayah.

(4) Pendirian BUM Desa bersama sebagaimana dimaksud pada ayat (3) tidak terikat pada batas wilayah administratif.

(5) Pendirian BUM Desa bersanra dilakukan Desa dengan Desa lain secara langsung tanpa mempertimbangkan ada atau tidaknya BUM Desa di Desa masingmasing.

(6) Peraturan Desa sebagaimana dimaksud pada ayat (1) dan Peraturan Bersama Kepala Desa selragaimana dirnaksud pada ayat (2) paling sedikit memuat:

a. penetapan pendirian BUM Desa/BUM Desa Bersama

b. Anggaran Dasar BUM Desa/BUM Desa bersama; dan

c. penetapan besarnya penyertaan modal Desa dan/atau rrrasyarakat Desa dalam rangka pendirian BUM Desa/B'UM Desa bersama.

Dalam pendirian BUM Desa/BUM Desa Bersama hendaknya di dasarkan pada pertimbangan- pertimbangan yang sesuai yang di amanahkan pada pasal 10 PP BUM Desa yang di antaranya:

a. Kebutuhan masyarakat

b. Pemecahan masalah bersama

c. Kekayaan usaha 

d. Model bisnis,tata kelola, bentuk organisasi dan jenis usaha, pengetahuan dan teknologi,
e. Visi pelestarian, orentasi keberlanjutan, dan misi perlindungan nilai religi, adat istiadat, perilaku social, dan kearifan lokal.

\section{b. Mekanisme BUM Desa/BUM Desa Bersama untuk memproleh Badan Hukum.}

Dengan disahkannya UU Cipta Kerja,status BUMDes secara tegas menjadi unit usaha berbadan hukum, BUMDes sebagai Badan Hukum entitas baru yang kedudukannya setara dengan Perseroan Terbatas (PT), serta setara dengan BUMN pada level nasional dan BUMD pada Level Daerah. Namun BUMDes memiliki Payung Hukum yang berbeda, Otoratifnya juga Berbeda karna desa adalah entitas khusus yang memiliki karaktristik tertentu dan UU Desa di berikan kekhususan, termasuk soal kemandirian desa yang sudah memiliki setting budaya berbeda.

Dalam PP BUM Desa, aturan pelaksana atas UU Cipta Kerja, bahwa BUM Desa atau BUM Desa bersama dalam memproleh status badan hukum terlebih dahulu harus mendapatkan registrasi dari Kementerian Desa, Pembangunan Daerah Tertinggal dan Transmigrasi (Kemendes PDTT) yang bertujuan untuk menghindari sejumlah hal seperti kesamaan nama. Setelah proses registrasi di Kemendes, kemudian di lanjutkan ke Kementerian Hukum dan HAM untuk di dokumentasikan. Ini dilakukan karena sebagai badan hukum, BUMDes bisa membuat Badan Hukum baru seperti Perseroan Terbatas (PT). Sebagaimana ketentuan dalam Pasal 8 PP BUM Desa menyatakan bahwa "BUM Desa/BUM Desa bersama memperoleh status badan hukum pada saat diterbitkannya sertifikat pendaftaran secara elektronik dari menteri yang menyelenggarakan urusan pemerintahan di bidang hukum dan hak asasi manusia. Dalam hal BUM Desa/BUM Desa bersama memiliki Unit Usaha BUM Desa/ EUM Desa bersama, kedudukan badan hukum unit usaha tersebut terpisah ctari BUM Desa/BUM Desa bersama sesuai dengan ketentuan peraturan perundang-undangan".
Selanjutnya ketentuan Pasal 9 PP BUM Desa menyatakan, "bahwa untuk rnemperoleh status badan hukum sebagaimana dimaksud dalam Pasal 8 ayat (1), Pemerintah Desa meiakukan pendaftaran BUM Desa/BUM Desa bersama kepada Menteri melaluri sistem informasi Desa yang terintegrasi dengan sistem administrasi badan hukum pada kementerian yang menyelengga, akan urusan pemerintahan di bidang hukum dan hak asasi manusia. Hasil pendaftaran BUM Desa/BUM Desa bersama menjadi dasar rnenteri yang menyelenggarakan urusan pemerintahan di bidang hukum dan hak asasi manusia untuk menerbitkan sertifikat pendaftaran badan hukum BUM Desa/BUM Desa bersama. ${ }^{55}$

Sebagaimana yang di maksud dalam Pasal 9 Ayat (4) PP BUM Desa pemerintah melalui kementerian terkait dalam hal ini Menteri Desa perlu menetapkan Peraturan Menteri Desa, sehingga terbitlah Peraturan Menteri Desa, Pembangunan Daerah tertinggal, dan Transmigrasi (Permen Desa PDTT) Nomor 3 Tahun 2021 Tentang Pendaftaran, Pendataan dan Pemeringkatan, Pembinaan dan Pengembangan, dan Pengadaan Barang Dan/atau Jasa Badan Usaha Milik Desa/ Badan Usaha Milik Desa Bersama. Yang dimana dalam Permen Desa PDTT ini dalam BAB II Dari Pasal 2 sampai Pasal 13 yang menyebutkan secara rinci mengenai Pendaftaran Nama dan Pendaftaran BUM Desa/ BUM Desa Bersama, sebagaimana di bawah ini: ${ }^{56}$

Pasal 2

(1) Pendaftaran nama BUM Desa/BUM Desa bersama dilakukan oleh pemohon melalui Sistem Informasi Desa.

(2) Pemohon sebagaimana dimaksud pada ayat (1) terdiri atas:

a. kepala Desa untuk BUM Desa; atau

b. kepala Desa yang diberi kuasa oleh para Kepala Desa

(3) sebagaimana dimaksud pada ayat (1) dilakukan sebelum pelaksanaan Musyawarah Desa/Musyawarah Antar

55 Ibid, Pasal 9

56 Republik Indonesia, Permendes, Pembangunan Daerah tertinggal,dan Transmigrasi, Nomor 3 tahun 2021 Tentang Tentang Pendaftaran, Pendataan dan Pemeringkatan, Pembinaan dan Pengembangan, dan Pengadaan Barang Dan/atau Jasa Badan Usaha Milik Desa/ Badan Usaha Milik Desa Bersama. 
Desa mengenai pendirian BUM Desa/BUM Desa Bersama kepala Desa Pasal 3 yang diberi kuasa oleh para Kepala Desa

(1) Pendaftaran nama BUM Desa/BUM Desa bersama sebagaimana dimaksud dalam Pasal 2 dilakukan secara elektronik dengan mengisi formulir isian pendaftaran nama BUM Desa/BUM Desa bersama.

(2) Formulir isian pendaftaran nama BUM Desa/BUM Desa bersama sebagaimana dimaksud pada ayat (1) memuat:
a. nama BUM Desa/BUM Desa bersama yang diajukan;
b. jenis BUM Desa:
1. BUM Desa; atau
2. BUM Desa bersama.
c. nama administratif Desa pendiri; dan
d. alamat kedudukan BUM Desa/BUM Desa bersama.

(3) Selain mengisi formulir isian pendaftaran nama BUM Desa/BUM Desa bersama sebagaimana dimaksud pada ayat (2), pemohon harus mengisi pernyataan secara elektronik yang menyatakan:
a. nama BUM Desa/BUM Desa bersama yang diajukan telah sesuai dengan ketentuan; dan
b. bertanggung jawab penuh terhadap nama BUM Desa/BUM Desa bersama yang diajukan.

Pasal 4

Nama BUM Desa/BUM Desa bersama sebagaimana dimaksud dalam Pasal 3 ayat (2) huruf a harus memenuhi ketentuan:

a. tidak sama atau tidak menyerupai nama:

1. BUM Desa/BUM Desa bersama lain;

2. Lembaga pemerintah; dan

3. Lembaga internasional;

b. diawali dengan frasa BUM Desa dan diakhiri dengan nama administratif Desa untuk BUM Desa;

c. diawali dengan frasa BUM Desa bersama untuk BUM Desa bersama;

d. tidak bertentangan dengan ketertiban umum dan/atau kesusilaan;

e. sesuai dengan atau mencerminkan maksud dan tujuan, serta usaha BUM Desa/BUM Desa bersama;

f. terdiri dari rangkaian huruf yang membentuk kata; dan

g. tidak mengandung bahasa asing Pasal 5
(1) Persetujuan penggunaan nama BUM Desa/BUM Desa bersama diberikan oleh Menteri secara elektronik.

(2) Persetujuan sebagaimana dimaksud pada ayat (1) diberikan dalam bentuk surat persetujuan penggunaan nama dalam Sistem Informasi Desa.

(3) Surat persetujuan sebagaimana dimaksud pada ayat (2) paling sedikit memuat:
a. nomor pendaftaran nama BUM Desa/BUM Desa bersama;
b. nama BUM Desa/BUM Desa bersama yang dapat dipakai;
c. nama pemohon;
d. tanggal pendaftaran nama BUM Desa/BUM Desa bersama; dan
e. tanggal kedaluwarsa.

(4) Surat persetujuan sebagaimana dimaksud pada ayat (2) hanya untuk 1 (satu) nama BUM Desa/BUM Desa bersama.

(5) Surat persetujuan sebagaimana dimaksud pada ayat (2) diberikan paling lama 1 (satu) hari kerja.

Pasal 6

(1) Dalam hal nama tidak memenuhi ketentuan sebagaimana dimaksud dalam Pasal 4, Menteri menolak nama BUM Desa/BUM Desa bersama secara elektronik.

(2) Penolakan nama BUM Desa/BUM Desa bersama diberikan paling lama 1 (satu) hari kerja.

Pasal 7

Nama yang telah disetujui sebagaimana dimaksud dalam Pasal 5 berlaku untuk jangka waktu paling lama 40 (empat puluh) hari kerja sejak persetujuan pemakaian nama diberikan.

Pasal 8

(1) Pendaftaran BUM Desa/BUM Desa bersama dilakukan oleh Pemerintah Desa kepada Menteri melalui Sistem Informasi Desa yang terintegrasi dengan sistem administrasi badan hukum kementerian yang menyelenggarakan urusan pemerintahan di bidang hukum dan hak asasi manusia.

(2) Pemerintah Desa sebagaimana dimaksud pada ayat (1) diwakili oleh pendaftar yang terdiri atas:

a. kepala Desa untuk BUM Desa; atau 
b. kepala Desa yang diberi kuasa oleh para kepala Desa dari Desa pendiri untuk BUM Desa bersama

Pasal 9

(1) Pendaftaran BUM Desa/BUM Desa bersama sebagaimana dimaksud dalam Pasal 8 dilakukan secara elektronik dengan mengisi formulir isian pendaftaran BUM Desa/BUM Desa bersama.

(2) Formulir isian pendaftaran BUM Desa/BUM Desa bersama sebagaimana dimaksud pada ayat (1) paling sedikit memuat:

a. nomor pendaftaran nama BUM Desa/BUM Desa bersama yang telah didapatkan pada proses pendaftaran nama;

b. nama BUM Desa/BUM Desa bersama yang telah disetujui oleh Menteri;

c. jenis BUM Desa:

1. BUM Desa; atau

2. BUM Desa bersama.

d. nama administratif Desa pendiri;

e. alamat BUM Desa/BUM Desa bersama;

f. modal awal BUM Desa/BUM Desa bersama;

g. identitas pendiri; dan

h. bidang usaha.

(3) Ketentuan mengenai nama administratif Desa pendiri sebagaimana dimaksud pada ayat (2) huruf $d$ dapat disesuaikan pada saat pendaftaran BUM Desa bersama.

(4) Pendaftaran sebagaimana dimaksud pada ayat (1) harus diajukan dalam jangka waktu paling lama 20 (dua puluh) hari kerja terhitung sejak tanggal ditetapkannya Peraturan Desa dan/atau Peraturan Bersama Kepala Desa mengenai pendirian BUM Desa/BUM Desa bersama.

(5) Dalam hal pendaftaran BUM Desa/BUM Desa bersama melebihi jangka waktu sebagaimana dimaksud pada ayat (3), pendaftar mengulang proses pendaftaran mulai dari pendaftaran nama BUM Desa/BUM Desa bersama.

Pasal 10

(1) Pengisian formulir isian pendaftaran BUM Desa/BUM Desa bersama sebagaimana dimaksud dalam Pasal 9 ayat (4) harus dilengkapi dengan dokumen pendukung yang disampaikan secara elektronik melalui Sistem Informasi Desa.

(2) Dokumen pendukung sebagaimana dimaksud pada ayat (1) berupa:

a. berita acara Musyawarah Desa/Musyawarah Antar Desa pendirian BUM Desa/BUM Desa bersama;

b. Peraturan Desa atau Peraturan Bersama Kepala Desa tentang pendirian BUM Desa/BUM Desa bersama dan Anggaran Dasar BUM Desa/BUM Desa bersama yang merupakan bagian tidak terpisahkan dari Peraturan Desa atau Peraturan Bersama Kepala Desa mengenai pendirian BUM Desa/BUM Desa bersama;

c. anggaran rumah tangga BUM Desa/BUM Desa bersama; dan

d. rencana program kerja BUM Desa/BUM Desa bersama.

(3) Format dokumen pendukung sebagaimana dimaksud pada ayat (2) tercantum dalam Lampiran I yang merupakan bagian tidak terpisahkan dari Peraturan Menteri ini.

Pasal 11

Pendaftar wajib mengisi pernyataan secara elektronik yang menyatakan:

a. dokumen pendukung pendaftaran BUM Desa/BUM Desa bersama telah lengkap dan benar;

b. formulir isian pendaftaran BUM Desa/BUM Desa bersama dan dokumen pendukung sebagaimana dimaksud dalam Pasal 9 telah sesuai dengan ketentuan peraturan perundang-undangan; dan

c. bertanggung jawab penuh terhadap formulir isian pendaftaran BUM Desa/BuM Desa bersama dan dokumen pendukung.

Pasal 12

(1) Verifikasi data pendaftaran sebagaimana dimaksud dalam Pasal 8 sampai dengan Pasal 11 dilakukan oleh Kementerian.

(2) Verifikasi sebagaimana dimaksud pada ayat (1) dilakukan paling lama 5 (lima) hari kerja terhitung sejak dilakukan pendaftaran melalui Sistem Informasi Desa.

(3) Data BUM Desa/BUM Desa bersama yang lolos verifikasi sebagaimana dimaksud 
pada ayat (2) disampaikan kepada menteri yang menyelenggarakan urusan pemerintahan di bidang hukum dan hak asasi manusia untuk diterbitkan sertifikat pendaftaran badan hukum BUM Desa/BUM Desa bersama.

(4) Data BUM Desa/BUM Desa bersama yang tidak lolos verifikasi sebagaimana dimaksud pada ayat (2) dikembalikan kepada pendaftar untuk diperbaiki

Pasal 13

Ketentuan mengenai alur roses pendaftaran BUM Desa/BUM Desa bersama tercantum dalam Lampiran II yang merupakan bagian tidak terpisahkan dari Peraturan Menteri ini.

Sebenarnya BUMDes di nyatakan sebagai badan hukum di mulai ketika desa menetapkan Peraturan Desa yang merupakan produk musyawarah desa di sahkan dan di tanda tangani oleh kepala desa, namun dalam PP BUM Desa yang di jelaskan di atas BUMDes harus menjalani proses registrasi di Kemendes PDTT. Hal ini bertujuan untuk menghindari sejumlah hal seperti kesamaan Nama, Kesamaan nama dengan Lembaga Pemerintah dan Lembaga Internasional. Setelah di registrasi di Kemendes kemudian dilanjutkan ke Kemenkumham untuk di dokumentasikan kemudian mengeluarkan Nomor Registrasi Badan Hukum. Ini dilakukan supaya BUMDes bisa badan hukum baru seperti Perseroan Terbatas (PT).

\section{Penghentian BUM Des/ BUM Desa Bersama}

Sebagaimana disebutkan dalam UU Cipta Kerja Bahwa BUM Des/BUM Bersama dan di PP BUM Desa/ BUM Desa Bersama yang merupakan aturan pelaksana dari UU Cipta Kerja. Bahwa BUMDes/ BUMDes Bersama secara tegas bersatatus Badan Hukum, sebagai Badan Hukum BUMDes ketika sudah di bentuk tidak bisa dibubarkan yang bisa hanya memberhentikan kegiatan usaha dari BUMDes tersebut. Dalam hal ini BUMDes bisa di berhentikan kegiatan usahanya apabila mengalami kerugian terus menerus yang tidak di dapat diselamatkan, dinyatakan pailit, mencemarkan lingkungan dan sebab-sebab lain yang sah sebagaimana yang tertera dalam PP BUM Desa pasal 64 ayat (1) dan (2).

Pemberhentian

BUMDes/BUMDes

Bersama sebagai mana di jelaskan dalam pasal 64 Ayat (5) di ikuti dengan penyelesaian seluruh kewajiban dan pembagian harta atau kekayaan hasil penghentian kegiatan usaha BUMDes/BUMDes Bersama kepada masingmasing penyerta modal dan kriditur yang di tunjuk penyelesaiannya melalui Musyawarah desa dan/atau Musyawarah Antar Desa.

Menurut penulis dalam hal BUMDes/ BUMDes Bersama tidak bisa di bubarkan yang ada hanya menghentikan kegiatan usahanya untuk menghindari kesewenang-wenangan Kepala Desa apabila ada hubungan yang tidak harmonis baik karena politik maupun yang lainnya antara Kepala Desa dan para Direksi BUMDes, yang ditakutkan ketika bisa di bubarkan maka akan rawan konflik pada BUMDes itu sendiri. Dan di khawatirkan lagi Kepala Desa semena-mena membubarkan yang lama kemudian mendaftarkan BUMDes yang baru. Oleh karena itu dalam PP BUM Des tidak mengenal kata membubarkan yang ada hanya bisa memberhentikan usaha dari BUMDes tersebut.

\section{d. Modal Dan Aset BUMDes/BUMDes Bersama}

Sebelumnya dalam UU Desa disebutkan bahwa modal BUMDes dimiliki oleh desa, sebab merupakan kekayaan desa yang diberikan melalui mekanisme penyertaan langsung. Namun ketentuan tersebut berubah setelah UU Cipta Kerja Berlaku dalam pasal 117 menyebutkan "Badan Usaha Milik Desa, yang selanjutnya di sebut BUM Desa adalah Badan Hukum yang di dirikan oleh desa dan/atau bersama desa-desa guna mengelola usaha ,memanfaatkan aset, mengembangkan investasi dan pruduktivitas, menyediakan jasa pelayanan, dan/atau jenis usaha lainnya untuk sebesar-besarnya kesejahteraan masyarakat desa". Ini menandakan bahwa desa hanya berperan untuk mengelola usaha dan aset yang sudah ada di BUM Des, hanya saja, Pemerintah desa bisa mendorong perkembangan BUMDes dengan memberikan hibah atau akses permodalan sebagaimana pada pasal 90 UU Desa yang tidak diubah dalam UU Cipta Kerja.

Modal awal BUM Desa/BUM Desa Bersama dapat berasal dari penyertaan modal desa dan penyertaan modal masyarakat desa yang dimana seluruh atau 
sebagian besar kepemilikan modal BUM Desa/BUM Desa Bersama di miliki oleh Desa atau Bersama Desa-Desa. Penyertaan modal masyarakat desa sebagaimana di jelaskan di atas dapat berasal dari lembaga berbadan Hukum, orang perseoragan, gabungan orang dari desa dan/atau dari desa-desa setempat yang semuanya baik yang dari penyertaan modal desa di putuskan dalam Musyawarah Desa dan/atau Musyawarah Antar desa. ${ }^{57}$

Konsekuensi dari BUMDes berbadan hukum adalah adanya pemisahan aset, karenanya BUMDes harus dipisahkan jelas mana aset desa mana aset BUMDes. Oleh karena itu dalam Pasal 45 - 47 PP BUM Desa yang merupakan aturan pelaksana dari UU Cipta Kerja Pasal 117 BUMDes/BUMDes Bersama ditegaskan bahwa desa memberikan modal kepada BUMDes yang dipisahkan atau dipindah tangankan ke BUMDes, sekali desa menyertakan modal ke BUMDes modal tersebut atau aset tersebut pindah tangan menjadi milik BUMDes.

\section{PENUTUP}

Dalam rangkan memajukan kesejahteraan Umum, Negara membentuk Badan Usaha Milik Negara (BUMN) yang sejarah terbentuknya adalah hasil dari nasionalisasi perusahaan-perusahaan Hindia Belanda paska Indonesia Merdeka yang dilakukan oleh presiden Soekarno. Dan juga amanat dari UUD NRI 1945 Pasal 33 Ayat (2) yang menyatakan bahwa "cabang-cabang produksi yang penting bagi negara dan yang menguasai hajat orang banyak di kuasai oleh Negara". Sehingga atas dasar inilah didirikan BUMN di atur secara tersendiri. BUMN dibagi menjadi tiga jenis yaitu Perusahaan Jawatan (PERJAN), Perusahaan Umum (PERUM) dan Perusahaan Persero (PERSERO) sebagai Mana yang tertera dalam UU 9/1969 dan kini berdasarkan UU 19/2003 Tentang BUMN, yang menurut UU ini Perusahaan Jawatan dirubah bentuknya menjadi Perusahaan Umum (PERUM) atau Perusahaan Perseroan (PERSERO).

BUMDes dirikan oleh pemerintah desa dengan harapan mampu menggerakkan roda prekonomian di pedesaaan. Namun

57 Republik Indonesia, Peraturan Pemerintah No 11 Tahun 2021 Tentang Badan Usaha Milik Desa, Pasal 40,41. permasalahan yang berbelit-belit terkait BUMDes ini karna Status BUMDes yang tidak jelas sebagai Badan Hukum sehingga akses permodalannya sulit di dapatkan hanya mengandalkan dari dana desa yang melalui penyertaan langsung. UU Desa dan PP Desa ini Status BUMDes sebagai Badan Usaha Berbadan Hukum menjadi sebuah permasalahan dan perdebatan yang sering muncul di masyarakat. Hal ini menimbulkan permasalahan ketika BUMDes ingin bekerja sama dengan pihak ketiga ataupun dari indepedensi BUMDes itu sendiri karena tidak ada regulasi yang secara tegas menyatakan BUMDes sebagai Badan Hukum.

Dengan lahirnya UU Cipta Kerja ini menegaskan setatus BUMDes sebagai badan Hukum, dan BUMDes memenuhi sebagai badan Hukum Publik, dengan demikian, BUMDes memiliki keperibadian hukum dan kapasitas hukum, khususnya dalam lapangan hukum keperdataan, dan perdebatan mengenai status BUMDes paska UU Cipta Kerja ini dianggap selesai. Bicara tentang badan hukum maka BUMDes harus teregistrasi di MENKUMHAM dengan proses pendaftaran oleh desa ke Kementerian Desa selanjutnya dari Kementerian Desa ke MENKUMHAM dan oleh MENKUMHAM diberikan Nomor Register maka BUMDes sah sebagai Badan Hukum. Dengan posisi BUMDes sebagai badan hukum ini banyak sekali yang bisa dilakukan oleh BUMDes, karena sebelumya tidak banyak yang bisa dilakukan sebelum UU Cipta Kerja berlaku, sebeb BUMDes hanya sebagai badan hukum atau sebagai badan usaha yang statusnya tidak Jelas. Salah satu yang bisa dilakukan oleh BUMDes sebagai badan hukum ialah BUMDes bisa mendirikan apa saja unit usaha yang berbadan hukum contoh BUMDes bisa mendirikan Perseroan Terbatas dan BUMDes juga bisa melakukan usaha di bidang penerangan bekerjasama dengan PLN, bekerjasama dengan BUMN, bekerjasama dengan Pertamina untuk mengadakan listrik desa, apakah dalam bentuk PLDes yang dikelola oleh BUMDes atau bekerja sama dengan BUMN atau BUMD.

Selain itu dalam UU Cipta Kerja dan PP BUMDesa aturan pelaksana dari UU Cipta Kerja bahwa di Setiap desa bisa mendirikan satu BUMDes tetapi satu BUMDes bisa memiliki sekian banyak usaha dan kemudian 
disebut juga dengan Badan Usaha Milik Desa Bersama (BUMDes Bersama) yaitu badan usaha milik desa yang didirikan oleh lebih dari satu desa yang kebetulan memiliki potensi desa yang sama untuk efektif kerjanya skalanya lebih luas maka bisa mendirikan BUMDes Bersama yang di dirikan dua desa tiga desa empat desa, bebas yang penting didasarkan pada dasar kesamaan potensi dan saling menguntungkan antara desa dengan desa yang lainnya, sesuai denagan prinsip dari pendirian BUMDes berdasarkan undang-undang Cipta kerja dan juga tidak kalah pentingnya organisasi BUMDes itu terpisah dari pemerintah Desa dengan demikian maka kepala desa tidak bisa mengintervensi kebijakan apapun di BUMDes di luar dari Kesepakatan atas apa yang disepakati di musyawarah desa.

\section{Buku}

\section{DAFTAR PUSTAKA}

Adisasmita, Rahardjo. Pengelolaan Pendapatan dan Anggaran Daerah. (Yogjakarta: GrahaIlmu, 2011).

Amiruddin, Zainal Asikin, Pengantar Metode Penelitian Hukum, Edisi Revisi (Jakarta: Raja Grafindo Persada, 2016).

Gunawan Nachrawi, BUMN Sebagai Usaha Pemerintah Menuju Kesejahteraan Rakyat, Tinjauan Filosopis,Sosiologis, Politik dan yuridis, (Cendekia press: Bandung, 2021)

M. Endriyo Susila et al, Buku Pedoman Penulisan Hukum, (Yogyakarta: Fakultas Hukum Universitas Muhammadiyah Yogyakarta, 2007).

Maryunani. Pembangunan BUMDes dan Pemberdayaan Pemerintah Desa. (Bandung: CV Pustaka Setia, 2008)

Mukti Fajar dan Yulianto Achmad, Dualisme Penelitian Hukum Normatif dan Empiris, Cetakan IV, (Yogyakarta: Pustaka Pelajar, 2017)
Kencana S, IImu Pemerintahan. (Semarang: Bumi Aksara, 2013).

Rosidin, Utang, Pemberdayaan Desa Dalam Sistem Pemerintahan Daereh. (Bandung: Pustaka Setia, 2019).

Sabian Utsman, Metodologi Penelitian Hukum Progresif, (Yogyakarta: Pustaka Pelajar, 2014).

Sahdan, dkk. ADD Untuk Kesejahteraan Masyarakat, (Yogyakarta: Forum Pengembangan Pembaharuan Desa (FPPD), 2006)

Soejono Soekanto dan Sri Mamudji, Penelitian Hukum Normatif Suatu Tinjauan Singkat, (Jakarta: PT RajaGrafindo Persada, 2014).

Soerjono Soekanto, Pengantar Penelitian Hukum, (Jakarta: Universitas Indonesia, 2014)

S., Ratna \& Djopari, J.R.G., Pengantar IImu Pemerintahan. Modul 2, (Tanggerang Selatan: Universitas Terbuka. 2017).

Wasino. Sejarah nasionalisasi aset-aset BUMN: dari perusahaan kolonial menuju perusahaan nasional / Wasino ... [et al.]. Jakarta: Kementerian BUMN RI, 2014

Peter Mahmud Marzuki, Penelitian Hukum, (Jakarta: Kencana, 2005).

Pramusinto, etl,. Reformasi Birokrasi, Kepemimpinan Dan Pelayanan Publik: Kajian Tentang Pelaksanaan Otonomi Daerah di Indonesia, (Yogyakarta: Gava Media, 2009).

\section{Jurnal dan Internet}

Alfiansyah, Setatus Badan Usaha Milik Desa Sebagai Badan Hukum Atas Di Undangkannya UndangUndang Cipta Kerja, Jurnal Ilmu Sosial dan Pendidikan, Vol. 5, No. 1, (Maret 2021)

Dedi Kusmana, Ismail, Manfaat Alokasi Dana Desa Bagi Pembangunan Dan Masyarakat Desa. Jurnal Otonomi Keuangan Daerah/Vol. 6/No. 1/Juni 2018 (81 - 100) 
Erni Herawati, 2016, Badan Usaha Milik Desa, Status dan

Pembentukannya, Bina Nusantara (online) https://businesslaw.binus.ac.id/2016/10/16/badan -usaha-milik-desa-status-danpembentukannya/\#, (26 juli 2021, jam 22:45)

Ginting, Yuni Priskila. "Holding Bumn Memerlukan Adanya Standar Prosedur Operasi Dalam Mencapai Aspek Tata Kelola Perusahaan Yang Baik. "Majalah Hukum Nasional 50, No. 1 (2020): 1-18. DOI: https://doi.org/10.33331/m hn.v50i1.53

Janah, Nur A.M. 2019. Makalah Perusahaan Jawatan. OSF Preprints. April 26. Doi: 10.31219/osf.io/mycp7

Riris Prasetyo, Sejarah BUMD, diakses https://asetdaerah.wordpress.co m/2011/07/15/sejarah-bumd/. Pada tanggal 15 juli 2021 pukul 23:14 WIB.

Rozik M. Kaelani, Landasan Hukum Dan Sejarah BUMN Di Indonesia, bulletin KAHMI FE Universitas Brawijaya, Edisi 1 Tahun 2007, dalam http://ketawanggede.tripod.com/ edisi1.pdf.

S. Dian Andryanto, "Hari ini Kelahiran Sumitro Djojohadikusumo, Peletak Dasar Ekonomi Pembangunan", Sabtu, 29 Mei 2021 16:51 WIB, https://nasional.tempo.co/read/1 466941/hari-ini-kelahiransumitro-djojohadikusumopeletak-dasar-ekonomipembangunan (diakses tanggal 7 Agustus 2021, pukul 10.09 Wita)

Yudho Taruno Muryoto,"Implikasi Yuridis Diundangkannya Undang-Undang Nomor 23 Tahun 2014 Tentang Pemerintah Daerah Terhadap Pengaturan Badan Usaha Milik Daerah Di Indonesia, "yustisia, Edisi 90, September- Desember 2014

\section{Undang-Undang}

Undang-Undang Nomor 86 Tahun 1958 Tentang Nasionalisasi Perusahaan-Perusahan Milik Belanda

Undang-Undang Nomor 5 Tahun 1962 Tentang Perusahaan Daerah

Undang-Undang Republik Indonesia Nomor 9 Tahun 1969 Tentang Penetapan Peraturan Pemerintah Pengganti Undang-Undang No. 1 Tahun 1969 Tentang BentukBentuk Usaha Negara Menjadi Undang-Undang

Undang-Undang Nomor 19 Tahun 2003 Tentang Badan Usaha Milik Negara

Undang-Undang Nomor 6 Tahun 2014 Tentang Desa

Undang-Undang Nomor 23 Tahun 2014 Tentang Pemerintahan Daerah

Undang-Undang Nomor 11 Tahun 2020 Tentang Cipta Kerja

Peraturan Pemerintah Nomor 43 tahun 2014 Tentang Pelaksanaan Undang-Undang Nomor 6 Tahun 2014 Tentang Desa.

Peraturan Pemerintah Nomor 11 Tahun 2021 Tentang Badan Usaha Milik Desa

Peraturan Menteri Dalam Negeri Nomor 39 Tahun 2010 Tentang Badan Usaha Milik Desa.

Peraturan Menteri Desa, Pembangunan Daerah tertinggal dan Transmigrasi Nomor 3 tahun 2021 Tentang Tentang Pendaftaran, Pendataan dan Pemeringkatan, Pembinaan dan Pengembangan, dan Pengadaan Barang Dan/atau Jasa Badan Usaha Milik Desa/ Badan Usaha Milik Desa Bersama. 